\title{
LGM Summer Climate on the Southern Margin of the Laurentide Ice Sheet: Wet or Dry?*
}

\author{
DAVID H. BROMWICH
}

Polar Meteorology Group, Byrd Polar Research Center, and Atmospheric Sciences Program, Department of Geography, The Ohio State University, Columbus, Ohio

\section{E. RICHARD TORACINTA}

Polar Meteorology Group, Byrd Polar Research Center, The Ohio State University, Columbus, Ohio

\section{Robert J. OgLesby}

NASA Marshall Space Flight Center, National Space Science and Technology Center, Huntsville, Alabama

\author{
James L. Fastook and Terence J. Hughes
}

Institute for Quaternary and Climate Studies, University of Maine, Bangor, Maine

(Manuscript received 31 May 2004, in final form 15 March 2005)

\begin{abstract}
Regional climate simulations are conducted using the Polar fifth-generation Pennsylvania State University (PSU)-NCAR Mesoscale Model (MM5) with a 60-km horizontal resolution domain over North America to explore the summer climate of the Last Glacial Maximum (LGM: 21000 calendar years ago), when much of the continent was covered by the Laurentide Ice Sheet (LIS). Output from a tailored NCAR Community Climate Model version 3 (CCM3) simulation of the LGM climate is used to provide the initial and lateral boundary conditions for Polar MM5. LGM boundary conditions include continental ice sheets, appropriate orbital forcing, reduced $\mathrm{CO}_{2}$ concentration, paleovegetation, modified sea surface temperatures, and lowered sea level.

The simulated LGM summer climate is characterized by a pronounced low-level thermal gradient along the southern margin of the LIS resulting from the juxtaposition of the cold ice sheet and adjacent warm ice-free land surface. This sharp thermal gradient anchors the midtropospheric jet stream and facilitates the development of synoptic cyclones that track over the ice sheet, some of which produce copious liquid precipitation along and south of the LIS terminus. Precipitation on the southern margin is orographically enhanced as moist southerly low-level flow (resembling a contemporary Great Plains low-level jet configuration) in advance of the cyclone is drawn up the ice sheet slope. Composites of wet and dry periods on the LIS southern margin illustrate two distinctly different atmospheric flow regimes. Given the episodic nature of the summer rain events, it may be possible to reconcile the model depiction of wet conditions on the LIS southern margin during the LGM summer with the widely accepted interpretation of aridity across the Great Plains based on geological proxy evidence.
\end{abstract}

\section{Introduction}

During the Last Glacial Maximum (LGM), a period roughly 21000 calendar years before present (21 kyr BP), the massive Northern Hemisphere continental ice

\footnotetext{
* Byrd Polar Research Center Contribution Number 1312.
}

Corresponding author address: Dr. David Bromwich, Byrd Polar Research Center, The Ohio State University, 1090 Carmack Road, Columbus, OH 43210-1002.

E-mail: bromwich@polarmet1.mps.ohio-state.edu sheets represented significant components of the climate system. The largest of these ice sheets - the Laurentide-covered much of North America with elevations above $3 \mathrm{~km}$ in what is now central Canada. At full size the southern terminus of the Laurentide Ice Sheet reached the middle latitudes of North America. Undoubtedly, the Laurentide Ice Sheet had a first-order impact on the large-scale atmospheric circulation in the Northern Hemisphere via topographic and thermal forcing as demonstrated in numerous global climate model (GCM) simulations (e.g., Manabe and Broccoli 1985; Kutzbach and Wright 1985; Rind 1987; Shinn and 
Barron 1989; Felzer et al. 1996; Kageyama and Valdes 2000; Toracinta et al. 2004). Although details vary among the modeling studies, they generally agree that the influence of the Laurentide Ice Sheet on the largescale atmospheric circulation is most pronounced in the winter months. Because insolation is at a minimum during boreal winter, thermal forcing (albedo effect) from the ice sheet is relatively small. Hence, Cook and Held (1988) attribute the influence of the Laurentide Ice Sheet on the wintertime atmospheric longwave pattern primarily to topographic forcing of strong midlatitude westerly flow impinging on the ice sheet. This is corroborated by recent high-resolution regional climate model (RCM) simulations of the LGM (Bromwich et al. 2004).

While the simulated atmospheric response to the presence of the Laurentide Ice Sheet is amplified during winter, the ice sheet response to the atmosphere occurs primarily in the warm season. That is, the distributions of summer temperature and precipitation, which are influenced by ice sheet topography, determine the location and rate of ice sheet growth or ablation and are therefore critical for ice sheet maintenance (Roe and Lindzen 2001). Modeling studies show that with increased insolation during summer, thermal forcing is enhanced due to the high albedo of the ice sheet (e.g., Rind 1987). The juxtaposition of cold surface temperatures over the ice sheet and relatively warm temperatures over the adjacent ice-free surface enhances the atmospheric baroclinicity along the southern ice sheet margin, which results in locally increased summer precipitation (Manabe and Broccoli 1985; Kutzbach and Wright 1985). In previous GCM simulations, this enhancement is confined to a relatively narrow zone on the southern or southeastern margin of the ice sheet, whereas much of the southern margin experiences reduced precipitation and negative ice mass balance (net ablation) during summer (Manabe and Broccoli 1985; Hall et al. 1996).

Results from several previous GCM simulations indicate that the region south of the Laurentide Ice Sheet (the Great Plains) was at least seasonally dry during the LGM (Manabe and Broccoli 1985; Kutzbach and Wright 1985; Kutzbach et al. 1993; Bartlein et al. 1998). Model predictions of aridity south of the Laurentide Ice Sheet are consistent with the distribution of loess (fine grain sediment) in the Great Plains, which, in some locales, is $30-40 \mathrm{~m}$ thick (Muhs and Bettis 2000). Much of this loess is thought to have formed from erosion of a sparsely vegetated landscape south of the Laurentide Ice Sheet terminus. The modern distribution of Great Plains loess has led to the inference of general aridity with prevailing westerly or northwesterly low-level winds to transport fine grain sediments from source regions to deposition regions in the Central Plains (Muhs et al. 1999; Muhs and Bettis 2000; Muhs and Zárate 2001; Mason 2001). The prevailing wind direction over the Great Plains at the LGM inferred from the loess record has yet to be reconciled with GCM predictions of predominantly northerly or northeasterly low-level winds generated by the broad anticyclonic circulation over the Laurentide Ice Sheet (Muhs and Zárate 2001).

Previous climate model studies of the summer climate of the LGM have relied on relatively coarse resolution GCMs. Yet, model resolution can have an important impact on a model's ability to accurately represent large-scale features, such as the atmospheric longwave pattern and storm tracks (Shinn and Barron 1989; Kageyama et al. 1999; Dong and Valdes 2000). Furthermore, mesoscale processes such as low-level jet maxima, which play a critical role in moisture transport and convective development in the central United States (e.g., Walters and Winkler 2001), become prevalent in the warm season but may not be adequately captured in coarse-resolution GCMs. Over the southwestern United States, Yang et al. (2001) find significant deficiencies in a GCM simulation of the summertime North American monsoon. Rind (1988) notes resolution dependency in simulated large-scale atmospheric dynamics and regional climate that are related to differences in the treatment of moist convection and nonlinear energy transfer. He cautions, however, that while finer-resolution models are better able to resolve local gradients, increased spatial resolution in GCMs does not guarantee better results in every respect.

Prior simulations of the contemporary climate have demonstrated that results from a RCM coupled to a GCM are more realistic than those from the GCM alone (Giorgi et al. 1990; Ji and Vernekar 1997). In future climate scenario simulations over the central Unites States, Pan et al. (2004) show that a RCM driven by large-scale forcing from a GCM captures important regional-scale processes associated with the Great Plains low-level jet, producing a hydrologic feedback mechanism that is not well simulated in the GCM. Applying this methodology to the LGM, Bromwich et al. (2004) simulated the winter climate over the Laurentide Ice Sheet using a RCM [Polar fifth-generation Pennsylvania State University (PSU)-National Center for Atmospheric Research (NCAR) Mesoscale Model (MM5) (PMM5)] coupled to the NCAR Community Climate Model, version 3 (CCM3; Kiehl et al. 1998). In their study, the Polar MM5 produced a split in the wintertime westerly jet stream around the Laurentide Ice Sheet. This circulation feature, which was not simulated 
by $\mathrm{CCM} 3$, accounted for substantial differences in the distribution of precipitation over North America between the regional and global models. The current study examines the LGM summer climate using output from June-July-August (JJA) of the coupled Polar MM5-CCM3 LGM simulation described in Bromwich et al. (2004). Our objectives are to 1) describe the characteristics of the summer atmospheric circulation over the Laurentide Ice Sheet as simulated by Polar MM5, 2) determine the sensitivity of the summer circulation to changes in ice sheet topography and the convective parameterization, and 3) relate the high-resolution model results to previous and current GCM results as well as climate conditions inferred from proxy data, particularly those in the U.S. Central Plains. Section 2 describes the Polar MM5, the LGM boundary conditions, and the approach used for the model experiments. Section 3 presents results from the LGM summer simulations along with results from sensitivity experiments. The discussion in section 4 includes comparisons of model output and proxy data and presents scenarios to reconcile the two. Concluding statements follow in section 5.

\section{Data and methods}

\section{a. Polar MM5 physics and LGM domain}

The Polar MM5 in the current study is a nonhydrostatic three-dimensional atmospheric model based on MM5 (Dudhia 1993; Grell et al. 1995) version 3.4 adapted specifically for simulations over polar regions. Polar MM5 has been tested extensively over presentday Greenland (Bromwich et al. 2001; Cassano et al. 2001) and Antarctica (Bromwich et al. 2003; Guo et al. 2003), and currently provides real-time numerical weather prediction in support of U.S. aircraft operations in Antarctica via the Antarctic Mesoscale Prediction System (AMPS) (Powers et al. 2003). Details of the optimized polar physics in Polar MM5 are provided elsewhere in the literature and are not repeated here. However, we note that contemporary Greenland and Antarctica likely represent the range of conditions that existed over the Laurentide Ice Sheet at the LGM and serve as reasonable analogs. Hence, Polar MM5 is well suited for simulations over the Laurentide Ice Sheet. The model configuration for the Polar MM5 LGM simulations is presented below.

\section{b. LGM boundary conditions}

The LGM ice sheet elevations are from the University of Maine Ice Sheet Model output (Fastook and Chapman 1989; Fastook and Prentice 1994). Relevant details of the ice sheet model are presented in Brom- wich et al. (2004). The ice sheet data were interpolated to the $60-\mathrm{km}$ Polar MM5 grid using a Cressman weighting scheme (Cressman 1959). Figure 1 shows the contoured LGM terrain elevations in the Polar MM5 domain. The Laurentide Ice Sheet, easily identifiable over North America, exceeds 3500-m elevation (above LGM sea level) just west of Hudson Bay in west-central Canada. The dome elevation is similar to that obtained from geophysically constrained ice sheet model simulations by Tarasov and Peltier (2004). The locations of the Laurentide Ice Sheet margins generally agree with reconstructions from geological data (e.g., Dyke et al. 2002), with the southern margin extending to about $39^{\circ} \mathrm{N}$, although the ice sheet model does not produce the detailed lobelike structures along the southern margin. Elsewhere, a substantial portion of the Fennoscandian Ice Sheet is included in the domain, covering much of the present day United Kingdom, Scandinavia, and Barents Sea; the maximum elevation exceeds $2400 \mathrm{~m}$ over northern Scandinavia and the ice sheet margins are in good agreement with recent reconstructions (Svendsen et al. 2004). In addition, a small ice cap covers the Cherskiy Mountains in eastern Russia $\left(65^{\circ} \mathrm{N}\right.$, $145^{\circ} \mathrm{E} ; 2100 \mathrm{~m}$ ). Over Alaska, Polar MM5 grid points were matched qualitatively to the Manley and Kaufman (2002) reconstruction of the LGM glacial extent. In the absence of proxy-based estimates of ice sheet thickness in the Alaska region, present-day terrain elevations (zero ice thickness) were retained at these model grid points, as in Bromwich et al. (2004).

Orbital forcing in Polar MM5 was set to $21 \mathrm{kyr}$ BP using the equations for eccentricity, declination, and longitude of perihelion from Berger (1977; Table 1). The atmospheric $\mathrm{CO}_{2}$ concentration was set to 180 ppm. Sea level was lowered $120 \mathrm{~m}$, which is commensurate with the LGM global ice sheet volume from glaciological model output but less than recent estimates of sea level lowering $(\sim 130 \mathrm{~m})$ based on marine evidence (Yokoyama et al. 2000; Peltier 2002). The lowered sea level exposes additional land primarily along the eastern coasts of Central and North America, the Bering Sea, and Bering Strait (Beringia; Fig. 1). Paleovegetation data from reconstructions over Beringia (Edwards et al. 2000), western North America (Thompson and Anderson 2000), and eastern North America (Williams et al. 2000) were matched to the 13-category MM5 vegetation types and qualitatively mapped to the ice-free land grid points in the Polar MM5 domain. Also following Bromwich et al. (2004), paleolakes Bonneville and Lahontan (in the Great Basin of the western United States) were implemented in the Polar MM5 domain using a depiction similar to that by Hostetler et al. (1994). 


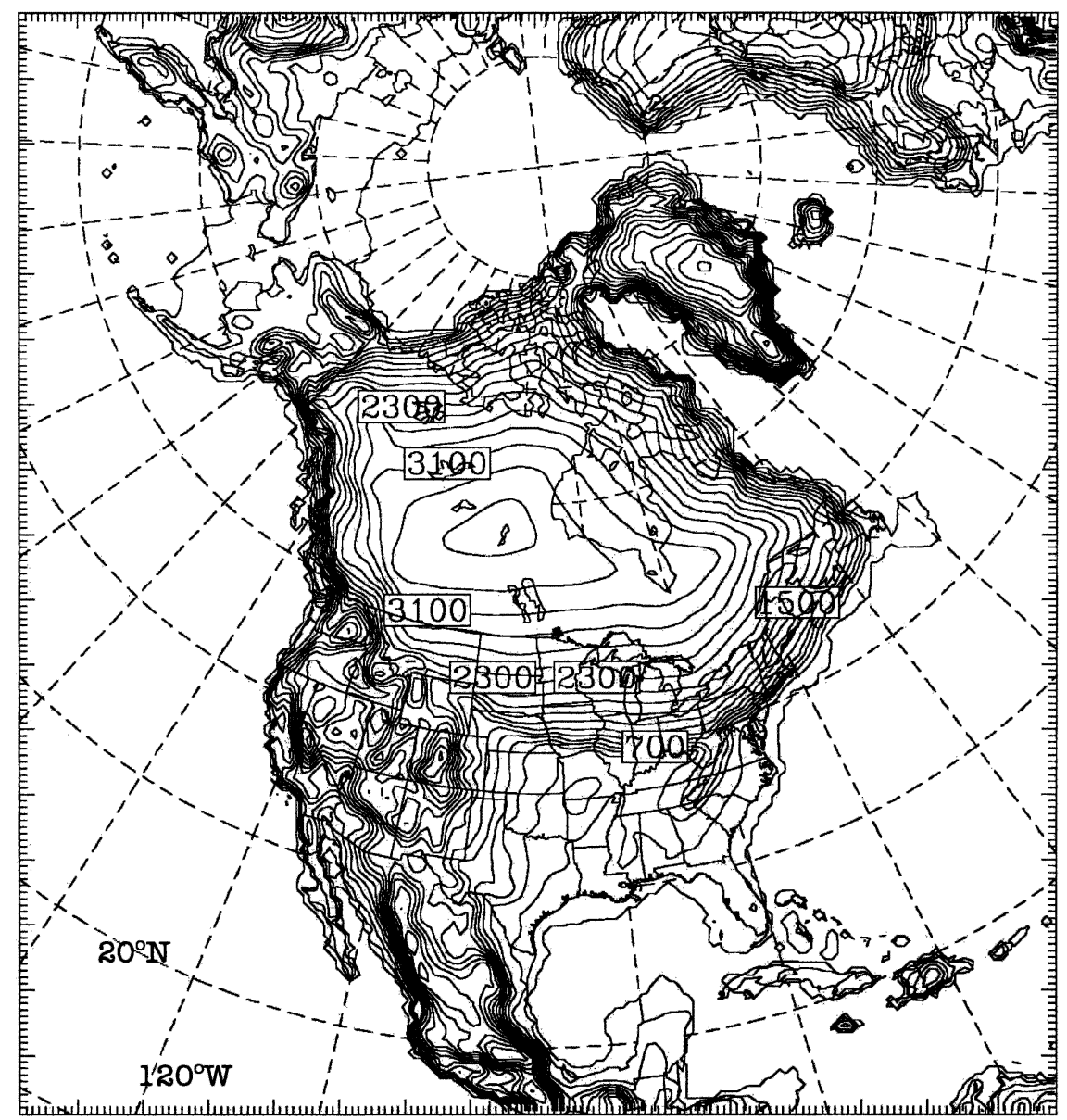

FIG. 1. The PMM5 LGM domain and terrain elevations contoured every $200 \mathrm{~m}$. Tick marks denote the $60-\mathrm{km}$ grid interval. Latitude and longitude lines have $10^{\circ}$ spacing. Note the additional land surface in some coastal locations (e.g., the Bering Strait) outlined by the $0-\mathrm{m}$ (sea level) contour on this topography map. For clarity, this additional land is not shown on later maps.

\section{c. PMM5 initial and lateral boundary conditions}

The initial and lateral boundary condition data for the Polar MM5 LGM simulations are from the final year of an 18-yr GCM simulation of the LGM climate using the NCAR CCM3 (Kiehl et al. 1998), the results of which are presented in detail by Toracinta et al. (2004). The NCAR CCM3 is a global spectral atmospheric model with T- 42 truncation $\left(2.8^{\circ}\right.$ latitude $\times 2.8^{\circ}$ longitude transform grid), 18 hybrid sigma levels in the

TABLE 1. Orbital parameters for the LGM and present day (Berger 1977).

\begin{tabular}{lcc}
\hline \hline & LGM & Present day \\
\hline Eccentricity & 0.01899 & 0.01672 \\
Obliquity & $22.949^{\circ}$ & $23.446^{\circ}$ \\
Longitude of perihelion & $114.42^{\circ}$ & $102.04^{\circ}$ \\
\hline
\end{tabular}

vertical, and a 20-min time step. The LGM boundary conditions in the CCM3 simulation were the same as those implemented in PMM5 except that the CCM3 configuration included a modified $\mathrm{CH}_{4}$ concentration (set to $350 \mathrm{ppbv}$ ) and present-day vegetation owing to significant uncertainties in current LGM global vegetation reconstructions. The relatively coarse spatial resolution in CCM3 means that the Laurentide Ice Sheet in CCM3 has a smoother and lower profile (e.g., 3200-m maximum elevation) than the representation in Polar MM5. Hence, it is possible that the ice sheet forcing of planetary waves in $\mathrm{CCM} 3$ is underestimated at the Polar MM5 lateral boundaries. Results from Goddard Institute for Space Studies (GISS) GCM simulations of the ice age climate indicate that ice sheet forcing of the large-scale atmosphere is relatively insensitive to model resolution in regions proximate to the ice sheets during summer (Rind 1988). 
Toracinta et al. (2004) used sea surface temperatures (SSTs) that were modified from the Climate: Long-Range Investigation, Mapping, and Prediction (CLIMAP; CLIMAP 1981) estimates based on a consensus from available proxy data. The modified LGM SSTs were cooled by $4^{\circ} \mathrm{C}$ uniformly in the Tropics $\left(30^{\circ} \mathrm{N}-30^{\circ} \mathrm{S}\right)$ relative to the CLIMAP annual mean and the high-latitude sea ice seasonal extent was reduced. For the current study, the prescribed monthly mean SSTs from the Toracinta et al. (2004) CCM3 simulation were interpolated to the Polar MM5 grid. The 12hourly CCM3 output, including the three-dimensional temperature, specific humidity, geopotential height, and wind fields as well as surface pressure, snow cover, soil moisture, and soil temperature, were interpolated to the Polar MM5 grid using the standard MM5 preprocessing routines.

The Polar MM5 LGM simulations were run for a complete annual cycle in a series of monthly runs, each preceded by a 2-week spinup period. As others have demonstrated, running a long regional climate simulation as a series of shorter, overlapping simulations can minimize model drift (Pan et al. 1999; Qian et al. 2003). Polar MM5 output was generated every three hours during May-September to adequately resolve the diurnal cycle. Monthly and composite JJA means of several model fields were computed for analysis and comparison with results from the CCM3 LGM simulation over the Polar MM5 domain.

\section{Results}

\section{a. JJA mean fields}

Figure 2 shows the mean JJA 2-m temperature, sea level pressure (SLP), near-surface (lowest sigma level) vector wind, and 500-hPa geopotential height distributions. Mean summer 2-m air temperatures (Fig. 2a) are lowest over central Greenland and just east of the Laurentide Ice Sheet summit. With the ice sheet buffered at freezing, the $0^{\circ} \mathrm{C}$ isotherm retreats to the Laurentide Ice Sheet margin in June where it remains through the summer months. In Fig. 2b, the Icelandic low is prominent over the North Atlantic and a trough of relatively low SLP extends southwestward along the Laurentide Ice Sheet margin between the subtropical high in the central Atlantic and the "glacial anticyclone" centered over the ice sheet. The mean JJA SLP field also indicates a monsoon trough over the southwestern United States.

Winds near the surface (Fig. 2c) are generally weak during summer with the exception of the easterly flow across the central Atlantic and Caribbean, northwesterly flow on the eastern slope of the Laurentide Ice
Sheet, and westerly flow across the North Atlantic. A weak divergent (katabatic) circulation is evident just south of the Laurentide Ice Sheet summit and maintains mean northeasterly near-surface winds along the southern margin in the central United States. The mean JJA 500-hPa geopotential heights and isotachs (Fig. 2d) indicate a nearly zonal midtropospheric flow traversing the southern margin of the Laurentide Ice Sheet. The broad trough over the North Atlantic, the closed circulation near Greenland, and the fast $\left(>30 \mathrm{~m} \mathrm{~s}^{-1}\right)$ transAtlantic flow are persistent large-scale features during the summer months.

The distribution of JJA accumulated precipitation (subgrid and large scale) is shown in Fig. 3. Consistent with the midtropospheric jet streamflow, a broad area of summer accumulated precipitation in excess of 200 mm extends from the eastern North Pacific, across the southern margin of the Laurentide Ice Sheet, and across the North Atlantic. The precipitation maximum over Great Britain is an orographic effect of the Fennoscandian Ice Sheet. Precipitation is also orographically enhanced in the summertime northwesterly flow regime over the High Canadian Arctic and northwestern Greenland. A pronounced precipitation maximum (>700 mm) occurs along the southern margin of the Laurentide Ice Sheet in the central United States. A distinct local maximum occurs along the southern margin in each of the summer months (not shown).

To explore the nature of this precipitation maximum, Fig. 4 shows the JJA time series of 3-hourly accumulated precipitation and the normalized time series of sea level pressure at a location on the Laurentide Ice Sheet southern margin $\left(40.6^{\circ} \mathrm{N}, 88.6^{\circ} \mathrm{W} ; 1099-\mathrm{m}\right.$ elevation) in the region of largest summer accumulation. The normalized time series shows substantial variability in SLP with periodic departures from the summer mean, indicative of the passage of synoptic-scale weather systems. Many of the negative SLP anomalies coincide with precipitation at this location, with the most significant event (three standard deviations from the mean) occurring in mid-July. Analysis of the 3-hourly SLP maps (not shown) indicates that this event is a succession of low pressure systems that form and propagate along the southern margin of the Laurentide Ice Sheet. To examine this case more closely, Fig. 5 a presents time series of SLP, 2-m air temperature, and meridional near-surface wind speed ${ }^{1}$ focused on the period 13-21 July. Figure $5 \mathrm{~b}$ shows the corresponding time series of 3-hourly accumulated precipitation, mean low-level

\footnotetext{
${ }^{1}$ At this location, the meridional wind component is approximately parallel to the ice sheet topographic gradient (i.e., either upslope or downslope).
} 

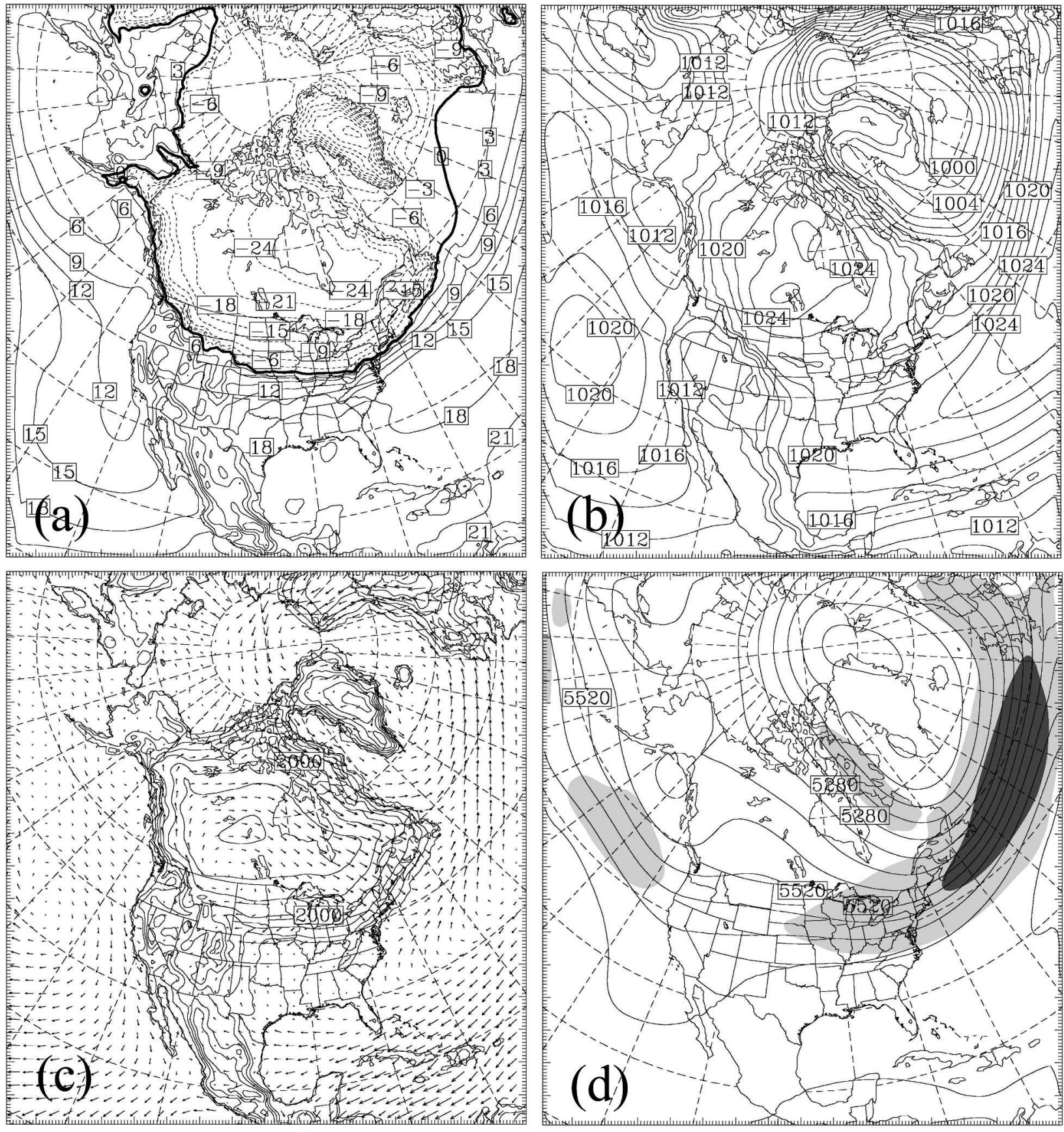

FIG. 2. Polar MM5 LGM mean Jun-Aug (a) 2-m air temperature (contoured every $3^{\circ} \mathrm{C}$ ), (b) sea level pressure (contoured every 2 $\mathrm{hPa}$ ), (c) near-surface vector wind and terrain elevation (contoured every $500 \mathrm{~m}$ ), and (d) 500-hPa geopotential height (contoured every $60 \mathrm{~m}$ ) and wind speed. Negative values in (a) are dashed and the $0^{\circ} \mathrm{C}$ isotherm is bold. In (d), regions with 500-hPa wind speeds exceeding 15 (30) $\mathrm{m} \mathrm{s}^{-1}$ are shaded light (dark) gray.

(lowest $0.5 \mathrm{~km}$ ) water vapor mixing ratio, and probability of liquid precipitation from the algorithm by Bocchieri (1980). In addition, to illustrate the upper-level and surface evolution of the case study, Fig. 6 shows the 500-hPa geopotential height distribution and absolute vorticity maxima (in excess of $15 \times 10^{-5} \mathrm{~s}^{-1}$ ) at select model times. The corresponding sea level pressure, near-surface vector wind, and 3-h accumulated precipitation distributions and the 2-m air temperature $0^{\circ} \mathrm{C}$ isotherm are shown in Fig. 7. For clarity, surface cy- 


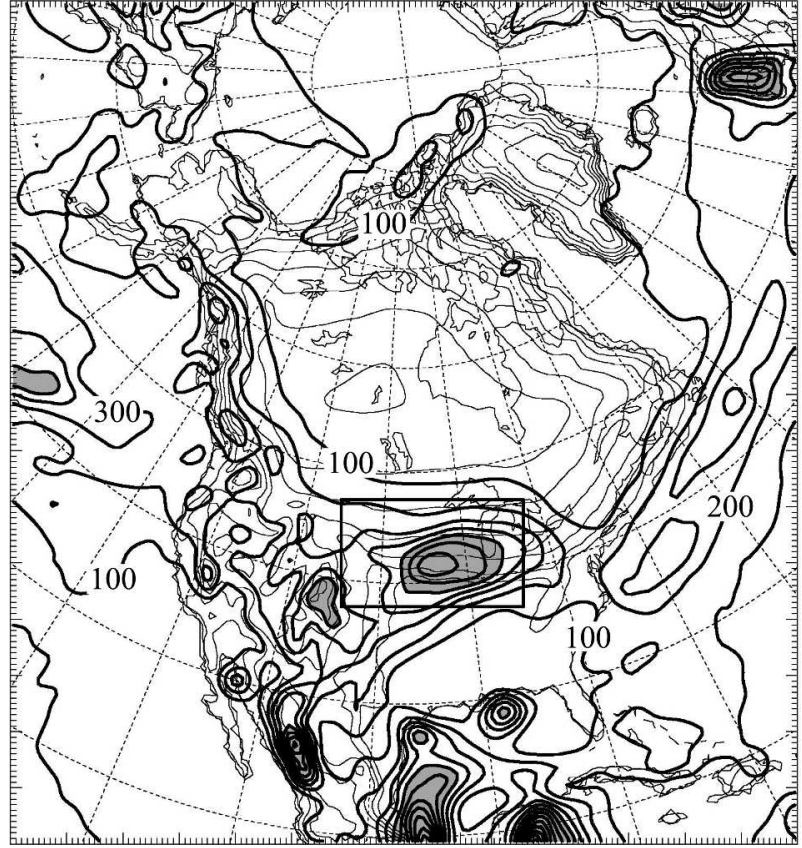

FIG. 3. Polar MM5 LGM JJA accumulated precipitation (thick contours) and terrain elevation. Terrain contour interval is $500 \mathrm{~m}$. Precipitation contour interval is $100 \mathrm{~mm}$, and regions with accumulations greater than $500 \mathrm{~mm}$ are shaded. The box denotes the region used to compute precipitation statistics in Table 2.

clones in Fig. 7 are numbered in the chronological order of their development. A gap in the numbering sequence in Fig. 7 indicates that a cyclone developed and dissipated (or moved out of the plot area) between the plotted times. $^{2}$

Early in the period, the diurnal cycle is evident in the 2-m temperature time series, where temperatures are below freezing under the influence of northerly (down slope) near-surface winds and relatively high SLP (Fig. 5a). A midtropospheric ridge axis is located near the station location (Fig. 6a) with a vorticity maximum upstream just south of the Laurentide Ice Sheet apex. The corresponding surface features, high pressure north of the Great Lakes and a 998-hPa surface cyclone (1) just south of the ice sheet apex, are evident in Fig. 7a. From 15-19 July, the flow regime changes as a series of upper-level disturbances and surface low pressure centers track along the ice sheet southern margin. Near-surface winds are predominantly southerly (upslope) at 7-15 $\mathrm{m} \mathrm{s}^{-1}$, resulting in an extended period of 2-m tempera-

\footnotetext{
${ }^{2}$ In the following analysis, the date/time notation is used merely for reference, where the beginning of the simulated month is 0000 UTC 1 Jul. Here and elsewhere, geographic features are referred to by their modern names (e.g., the Great Lakes, Lake Winnipeg, Rocky Mountains).
}

tures above freezing (Fig. 5a) and a marked increase in low-level moisture (Fig. 5b). By 1200 UTC 16 July, the 500-hPa vorticity maximum and low amplitude short wave have translated downstream as another impulse crosses the Rocky Mountains just to the west (Fig. 6b). At the surface, cyclone $\mathbf{1}$ has weakened and is located south of Lake Winnipeg, while a secondary cyclone (2) has developed over the Great Lakes (Fig. 7b). This secondary surface cyclone has a distinct warm sector, as indicated by the northward kink in the $2-\mathrm{m} 0^{\circ} \mathrm{C}$ isotherm, and is producing rain on the southern margin of the ice sheet.

By 0000 UTC 19 July, the second 500-hPa vorticity maximum has moved from the Rocky Mountains eastward to Lake Winnipeg (Fig. 6c). At the surface (Fig. 7c), an occluded cyclone is located near Lake Winnipeg (4) with a secondary cyclone over the eastern Great Lakes (5). Warm southerly flow persists along the southern margin with peak rainfall at the station location due to a frontal boundary, evident in the nearsurface wind field. By 1200 UTC 19 July, surface cyclone 5 has dissipated and another cyclone (6) develops near the station location (not shown). As the upperlevel short wave and mature surface cyclone pass late in the period (Figs. 6d, 7d), there is an abrupt return to northerly near-surface winds and a colder, drier air mass at the station location (Figs. 5a,b). During the 5-day event, nearly $215 \mathrm{~mm}$ of precipitation (almost certainly rain) occurs at this location on the Laurentide Ice Sheet. Although the mid-July case is the most highly amplified of those that occur along the southern margin of the ice sheet during summer, each of the other cases has similar characteristics, most notably the period of warm advection and the high probability of liquid precipitation. Such rain events have important implications for glacier dynamics since they are a potentially important source of water to lubricate the ice sheet bed along the southern margin of the ice sheet (e.g., Zwally et al. 2002).

To illustrate the general synoptic conditions associated with summer cyclones that traverse the southern margin of the Laurentide Ice Sheet, the precipitation events from Fig. 4 have been averaged into a "wet" composite. Likewise, periods of cyclone inactivity on the southern margin, defined as periods between precipitation events in Fig. 4, are averaged into a "dry" composite. Several anomaly fields (wet composite minus summer mean) are presented in Fig. 8. Periods of cyclone activity on the southern margin are associated with negative 500-hPa height anomalies (troughing) over central North America and positive height anomalies (ridging) downstream over eastern North America (Fig. 8a). There is an attendant decrease in SLP over 


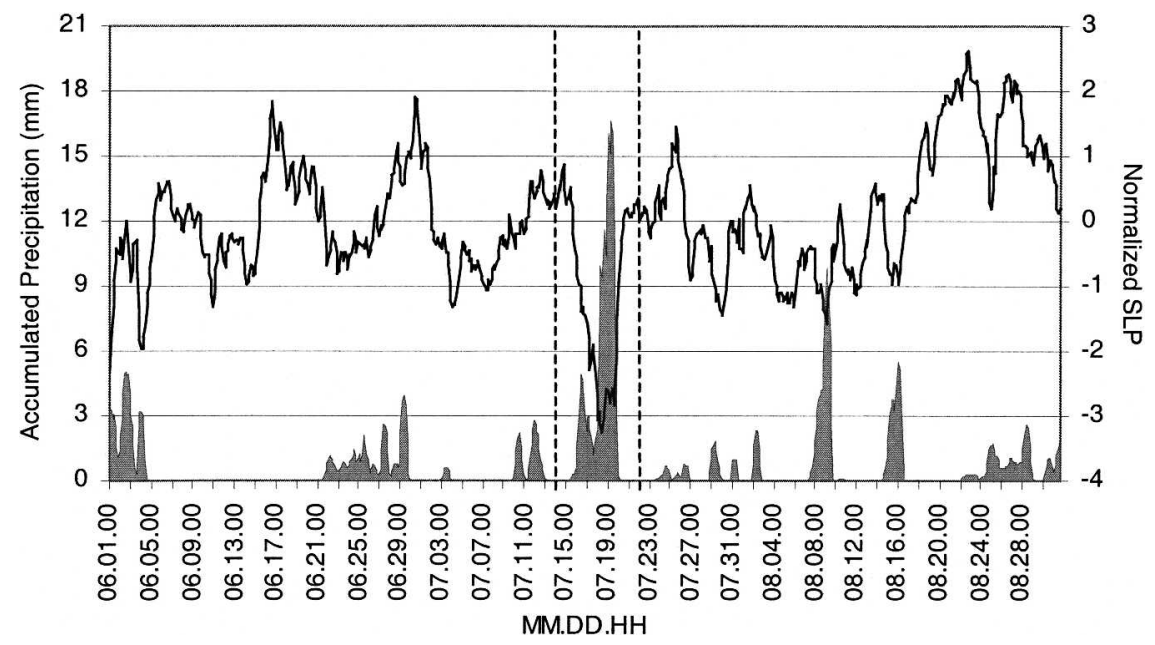

FIG. 4. Polar MM5 LGM JJA time series of 3-hourly accumulated precipitation (mm; shaded) and normalized time series of sea level pressure at a station located on the southern margin of the Laurentide Ice Sheet $\left(40.6^{\circ} \mathrm{N}, 88.6^{\circ} \mathrm{W} ; 1099-\mathrm{m}\right.$ elevation). Departures from the summer mean SLP are normalized by the summer standard deviation. Vertical dashed lines denote the case study time range (see Fig. 5).

the southern portion of the ice sheet and central Great Plains along with increased low-level moisture, represented by the mean $\Theta_{e}$ in the lowest $0.5 \mathrm{~km}$ (Fig. 8b). The largest positive mean $\Theta_{e}$ anomalies are located over the central Great Plains, immediately east of the largest negative SLP anomalies. The SLP anomalies correspond to a marked increase in mean low-level $(0.5-1.5 \mathrm{~km})$ southerly flow over the southern and central Great Plains. In fact, the wet composite mean lowlevel isotach-streamline configuration over the central United States (not shown) strongly resembles a contemporary warm season Great Plains southerly lowlevel jet configuration (Walters and Winkler 2001). This indicates that the low-level jet is an important moisture transport mechanism at the LGM with the Gulf of Mexico and Caribbean serving as primary moisture sources for cyclones along the Laurentide Ice Sheet southern margin.

The dry composite anomalies in Fig. 9 have the opposite sign and approximately the same magnitude and location as the wet composite anomalies. Hence, periods of cyclone inactivity along the ice sheet southern margin are characterized by ridging in the midtroposphere over central North America and troughing downstream over eastern North America (Fig. 9a). There are attendant increases (decreases) in SLP (lowlevel moisture) over the Great Plains and southern margin of the ice sheet (Fig. 9b). As the dry composite SLP anomalies suggest, periods of cyclone inactivity are marked by anticyclonic low-level circulation over central North America with marked increases in northerly flow over the southern margin of the ice sheet relative to the summer mean (not shown).

\section{b. Sensitivity experiments}

The magnitude of precipitation occurring on the southern margin of the Laurentide Ice Sheet, and the high probability that it is rain, is a significant and somewhat unexpected result of the Polar MM5 LGM summer simulations. Several sensitivity experiments were conducted to better assess the nature of these rain events using July as the representative summer month. Quantitative differences are made using the July simulation with full LGM boundary forcing and physics options (as described in section 2) as the control. In a few instances below, qualitative comparisons are made with the mean JJA fields shown previously since these are generally similar to the July LGM control run.

\section{1) Flat Laurentide Ice Sheet}

The first sensitivity experiment examines the role of ice sheet elevation (e.g., orographic forcing) by replacing the Laurentide Ice Sheet with a flat ice sheet. Others have examined the effects of flat ice sheets on the LGM summer climate using coarse-resolution GCMs (Rind 1987; Felzer et al. 1996). Here, a zero thickness Laurentide Ice Sheet was implemented in Polar MM5 by setting the terrain elevation at each ice sheet grid point to its nonglaciated value and retaining the land ice surface type. All other initial and boundary conditions and physics options (e.g., cloud microphysics and subgrid cumulus parameterization) were unchanged. 
(a)

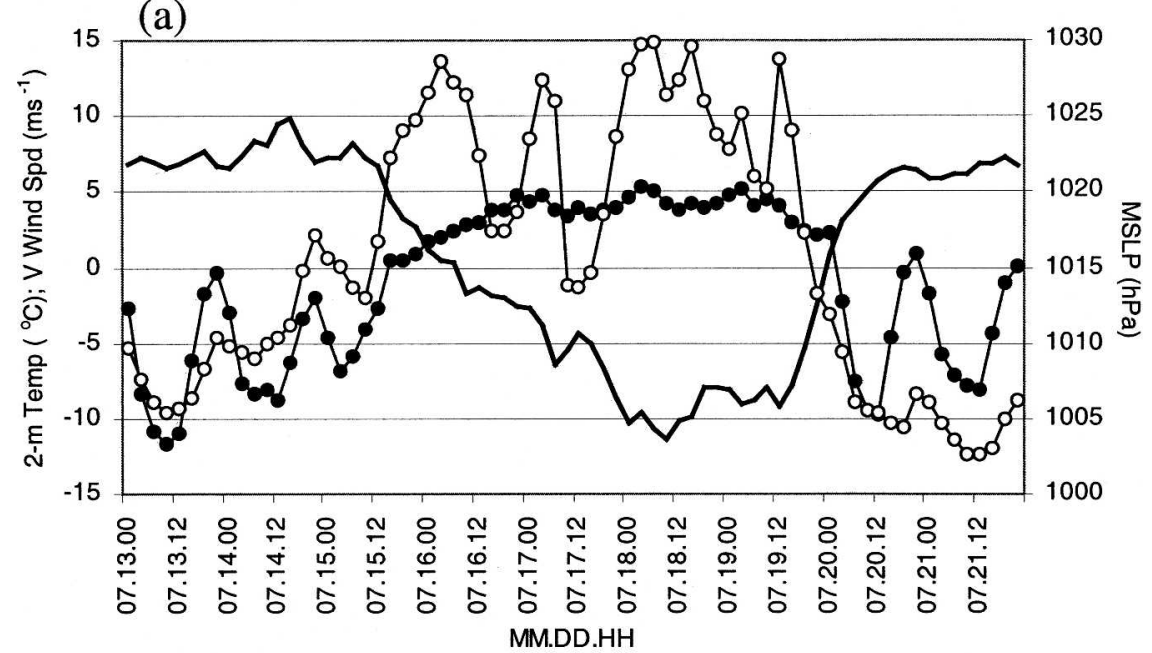

(b)

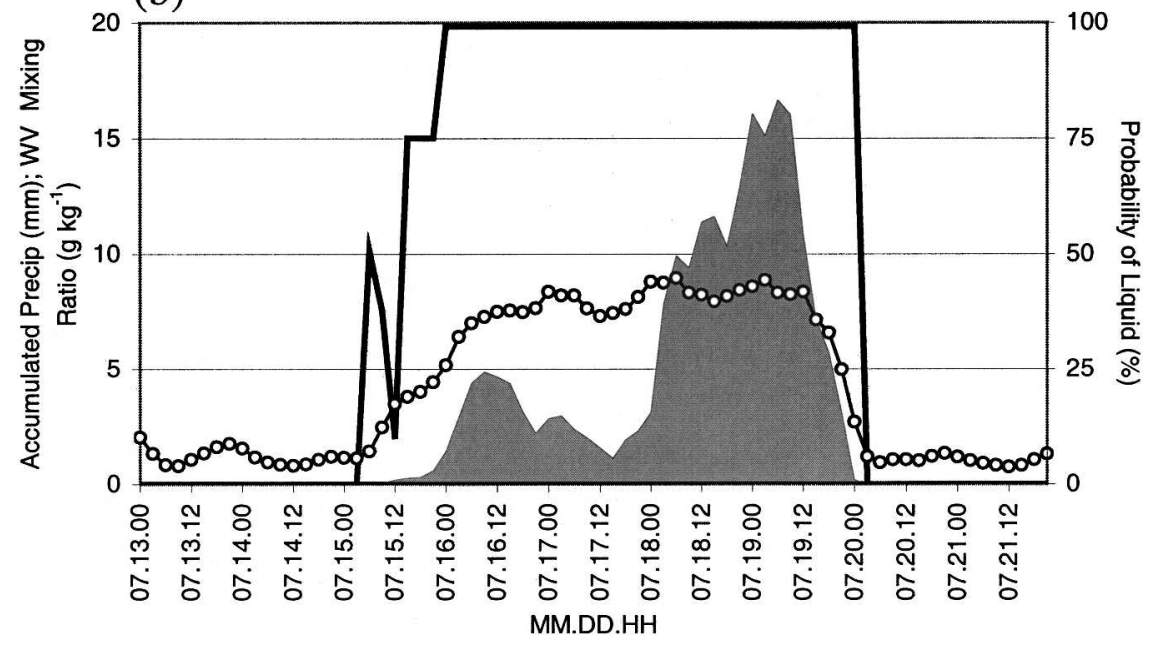

FIG. 5. Polar MM5 LGM 13-21 Jul time series of (a) 2-m temperature $\left({ }^{\circ} \mathrm{C}\right.$; filled circles), meridional wind speed $\left(\mathrm{m} \mathrm{s}^{-1}\right.$; open circles), and mean sea level pressure ( $\mathrm{hPa}$; bold); (b) 3-hourly accumulated precipitation ( $\mathrm{mm}$; shaded), mean water vapor mixing ratio in the lowest $0.5 \mathrm{~km}$ ( $\mathrm{g} \mathrm{kg}^{-1}$; open circles) and probability of liquid precipitation (\%; bold). Station is located on the southern margin of the Laurentide Ice Sheet $\left(40.6^{\circ} \mathrm{N}, 88.6^{\circ} \mathrm{W} ; 1099-\mathrm{m}\right.$ elevation).

The mean July 500-hPa geopotential height field in the flat ice sheet case is dominated by a large cyclonic gyre located over the Canadian High Arctic (Fig. 10a). The midtropospheric flow is weaker and the jet stream positioned farther north than in the control run (cf. Fig. $2 \mathrm{~d})$. At the surface, broad centers of low and high sea level pressure are located over Baffin Island and the mid-Atlantic coast, respectively (Fig. 10b). The latter represents a significant westward displacement of the Atlantic subtropical high relative to the control run. Relatively large sea level pressure gradients are located over the Caribbean and Gulf of Mexico, as well as eastern Canada and the North Atlantic, resulting in enhanced near-surface wind flow over these regions (Fig. 10c). The mean southerly low-level flow over central North America contributes to relatively warm 2-m air temperatures on the southern margin of the flat ice sheet (Fig. 10d).

The mean July 2-m air temperature anomalies (flat minus full ice sheet) are shown in Fig. 11a. The anomalies were computed by first adjusting the 2-m temperatures at each Laurentide Ice Sheet grid point by the elevation difference between the full and flat ice sheet topography using a $6^{\circ} \mathrm{C} \mathrm{km}^{-1}$ atmospheric lapse rate. Steffen and Box (2001) report an annual mean lapse rate of $7.1^{\circ} \mathrm{C} \mathrm{km}^{-1}$ along the slope of the Greenland Ice Sheet with lower monthly mean values $\left(4.0-5.0^{\circ} \mathrm{C}\right.$ $\mathrm{km}^{-1}$ ) during summer at sites on the western slope. 

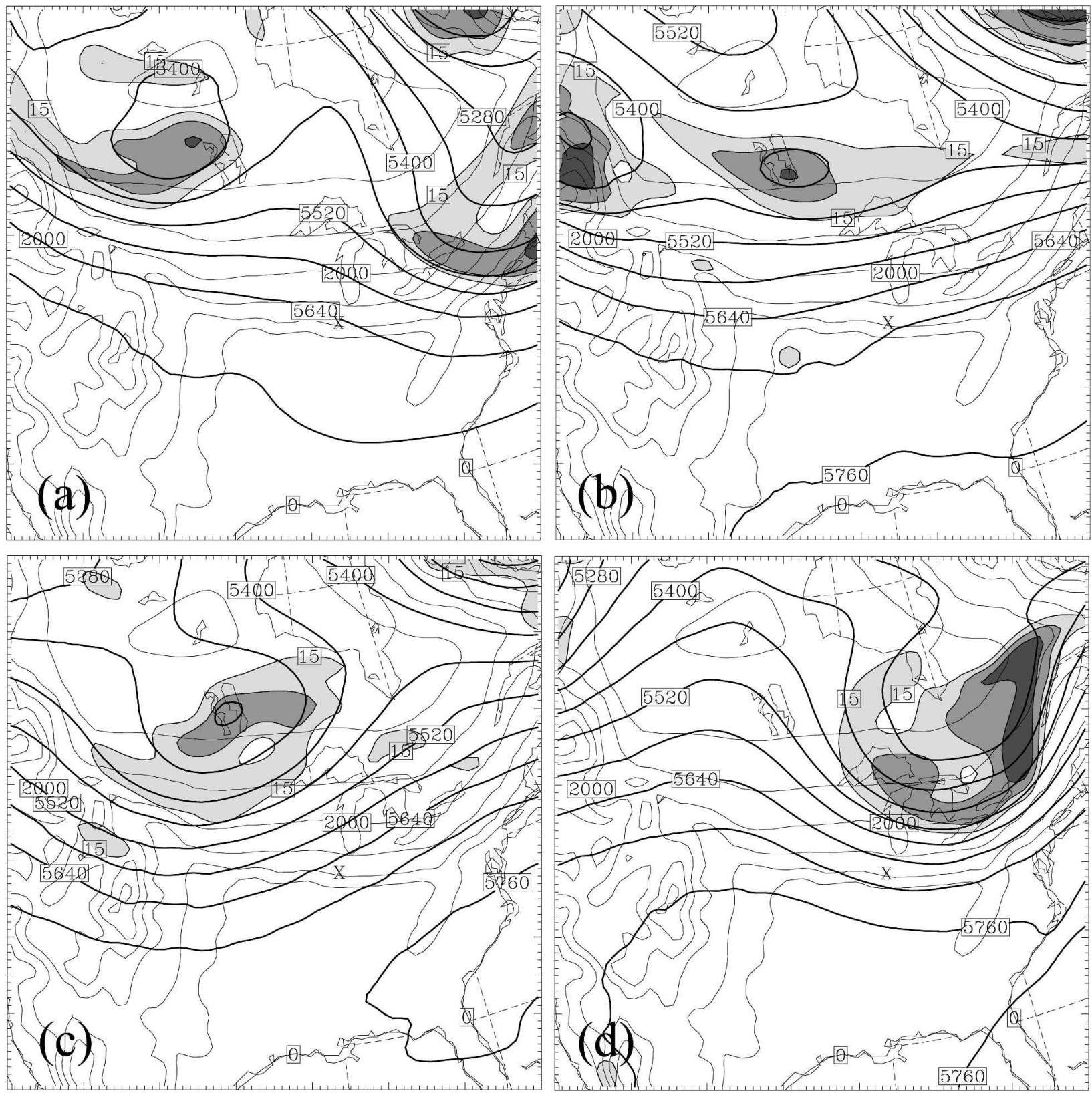

FIG. 6. Polar MM5 Jul terrain elevation (thin solid), 500-hPa geopotential height (bold solid), and 500-hPa absolute vorticity exceeding $15 \times 10^{-5} \mathrm{~s}^{-1}$ (shaded) at model day/hour (a) 14/0000 UTC, (b) 16/1200 UTC, (c) 19/0000 UTC, and (d) 21/1200 UTC. Terrain contour interval is $500 \mathrm{~m}$. Geopotential height contour interval is $60 \mathrm{~m}$. Absolute vorticity shading interval is $3 \times 10^{-5} \mathrm{~s}^{-1}$. The station location for the time series data in Figs. 4 and 5 is indicated by an " $\mathrm{X}$ " at $40.6^{\circ} \mathrm{N}, 88.6^{\circ} \mathrm{W}$ on the southern margin of the Laurentide Ice Sheet.

Positive elevation-adjusted temperature anomalies extend along the southern margin and over most of the eastern portion of the ice sheet. Comparison of the mean near-surface winds over the flat ice sheet (Fig. 10c) and full ice sheet (Fig. 2c) suggests that the negative temperature anomalies over northern and central Canada are attributed to cold air advection, whereby air parcels from the cold Arctic basin traverse unim- peded over the flat ice sheet. The absence of orographic forcing in the flat ice sheet case also allows moisture to advect farther northward, resulting in reduced precipitation on the southern margin but increased precipitation farther north on the ice sheet (Fig. 11b). This pattern of cold advection and moisture availability in the absence of an elevated ice sheet has important implications for glacial initiation (e.g., Lamb and Woodroffe 

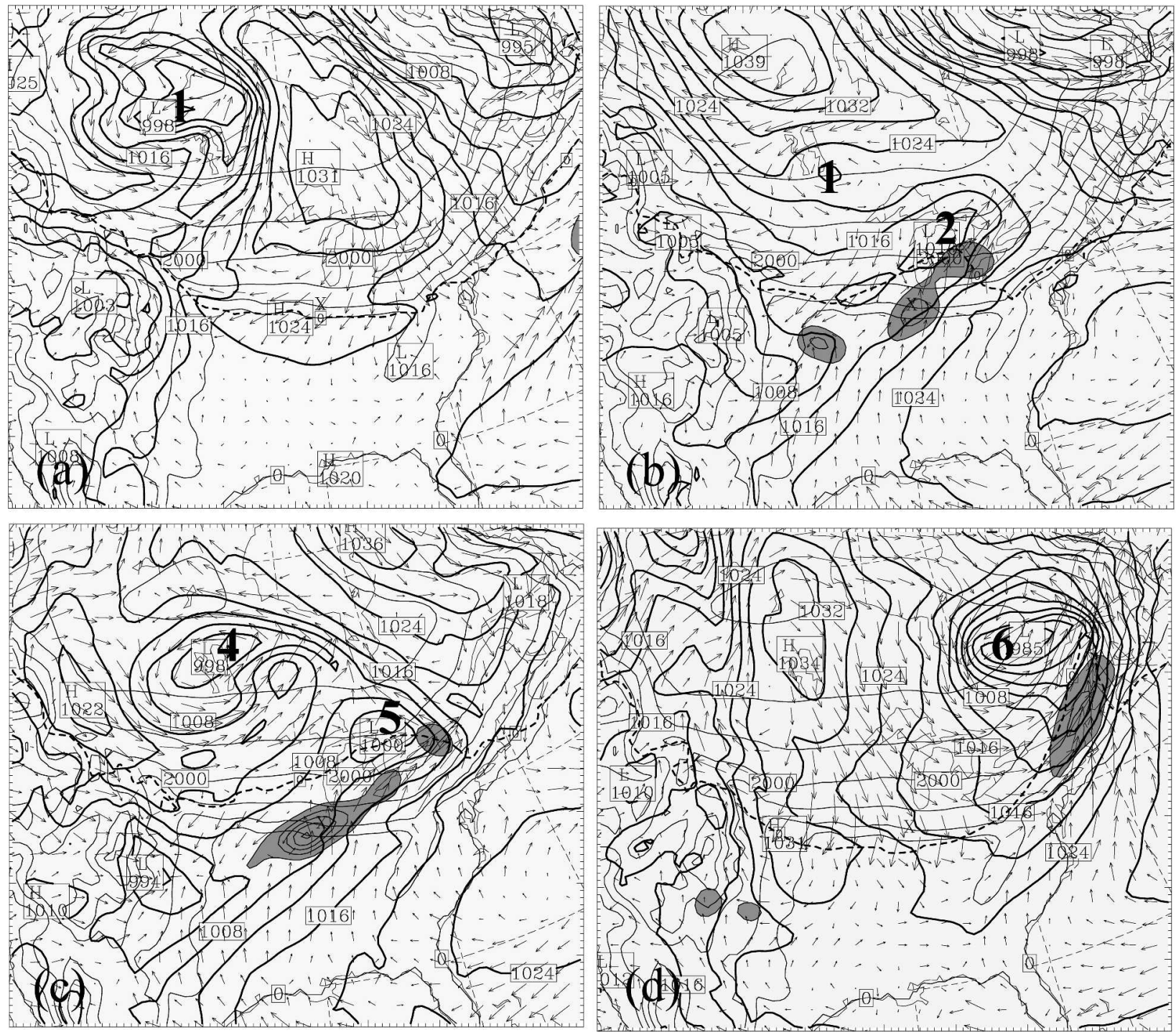

FIG. 7. Polar MM5 Jul terrain elevation (thin solid), sea level pressure (bold solid), 2-m air temperature $0^{\circ} \mathrm{C}$ isotherm (dashed), near-surface wind (vectors), and 3-hourly accumulated precipitation (shaded) at model day/hour (a) 14/0000 UTC, (b) 16/1200 UTC, (c) 19/0000 UTC, and (d) 21/1200 UTC. Terrain contour interval is $500 \mathrm{~m}$; SLP contour interval is $4 \mathrm{hPa}$; precipitation contour interval is $3 \mathrm{~mm}$. The station location for the time series data in Figs. 4 and 5 is indicated by an " $\mathrm{X}$ " at $40.6^{\circ} \mathrm{N}, 88.6^{\circ} \mathrm{W}$ on the southern margin of the Laurentide Ice Sheet. Surface cyclones are numbered chronologically (see text).

1970; Felzer et al. 1996). Conversely, the sensitivity experiment demonstrates the importance of the ice sheet slope to orographically enhance precipitation on the southern margin. The positive precipitation anomalies in the Gulf of Mexico are due, in part, to stronger easterly near-surface winds and increased low-level convergence in the flat ice sheet experiment.

\section{2) Convective scheme}

Atmospheric convection is an important mechanism for the vertical redistribution of heat and moisture and it accounts for a significant portion of summertime precipitation in many regions of present-day North America. At the LGM, most summer convective precipitation occurs well south of the Laurentide Ice Sheet (Fig. 12), accounting for more than $30 \%$ of the summer total precipitation in some locales. Convective precipitation also occurs on the southern margin of the ice sheet, although it represents a small fraction $(<5 \%)$ of the summer total. In the current LGM control simulations, convective processes are parameterized by the commonly used Grell scheme (Grell et al. 1995). The Grell cumulus parameterization is a simple single-cloud 

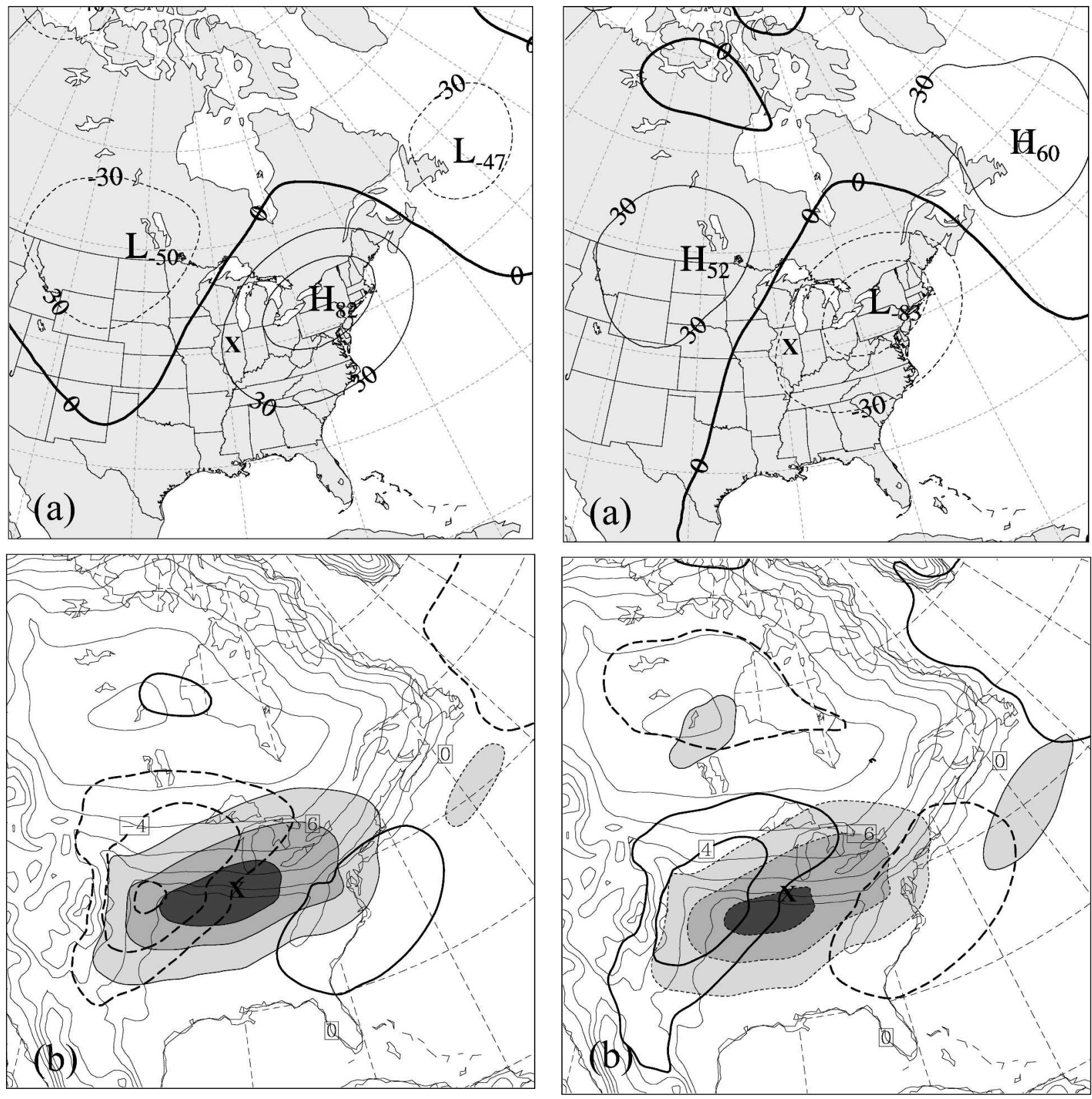

FIG. 8. Polar MM5 LGM JJA (a) 500-hPa geopotential height difference ("wet composite" minus summer mean); (b) sea level pressure difference (thick contours), mean low-level (surface to $0.5 \mathrm{~km}$ ) equivalent potential temperature difference (shading), and terrain elevation (thin contours). Contour interval is $30 \mathrm{~m}$ in (a). In (b), SLP anomaly contour interval is $2 \mathrm{hPa}$, and negative anomalies are dashed. The $\Theta_{e}$ anomaly contour interval is $3 \mathrm{~K}$, and negative anomalies are dotted. Terrain contour interval is 500 $\mathrm{m}$. The composites were computed using data from the grid location denoted by an "X."

scheme based on the rate of destabilization of the atmosphere where convective updraft and downdraft fluxes and compensating vertical motion determine the heating and moistening of the atmospheric column.

FIG. 9. Polar MM5 LGM JJA (a) 500-hPa geopotential height difference ("dry composite" minus summer mean), (b) sea level pressure difference (thick contours), mean low-level (surface to $0.5 \mathrm{~km}$ ) equivalent potential temperature difference (shaded), and terrain elevation (thin contours). Contour interval is $30 \mathrm{~m}$ in (a). In (b), SLP anomaly contour interval is $2 \mathrm{hPa}$, and negative anomalies are dashed. The $\Theta_{e}$ anomaly contour interval is $3 \mathrm{~K}$, and negative anomalies are dotted. Terrain contour interval is 500 $\mathrm{m}$. The composites were computed using data from the grid location denoted by an "X."

Mixing of cloud and environmental properties takes place only at the top and bottom of the updraftdowndraft couplet (i.e., lateral mixing is not considered). The effects of wind shear on precipitation effi- 

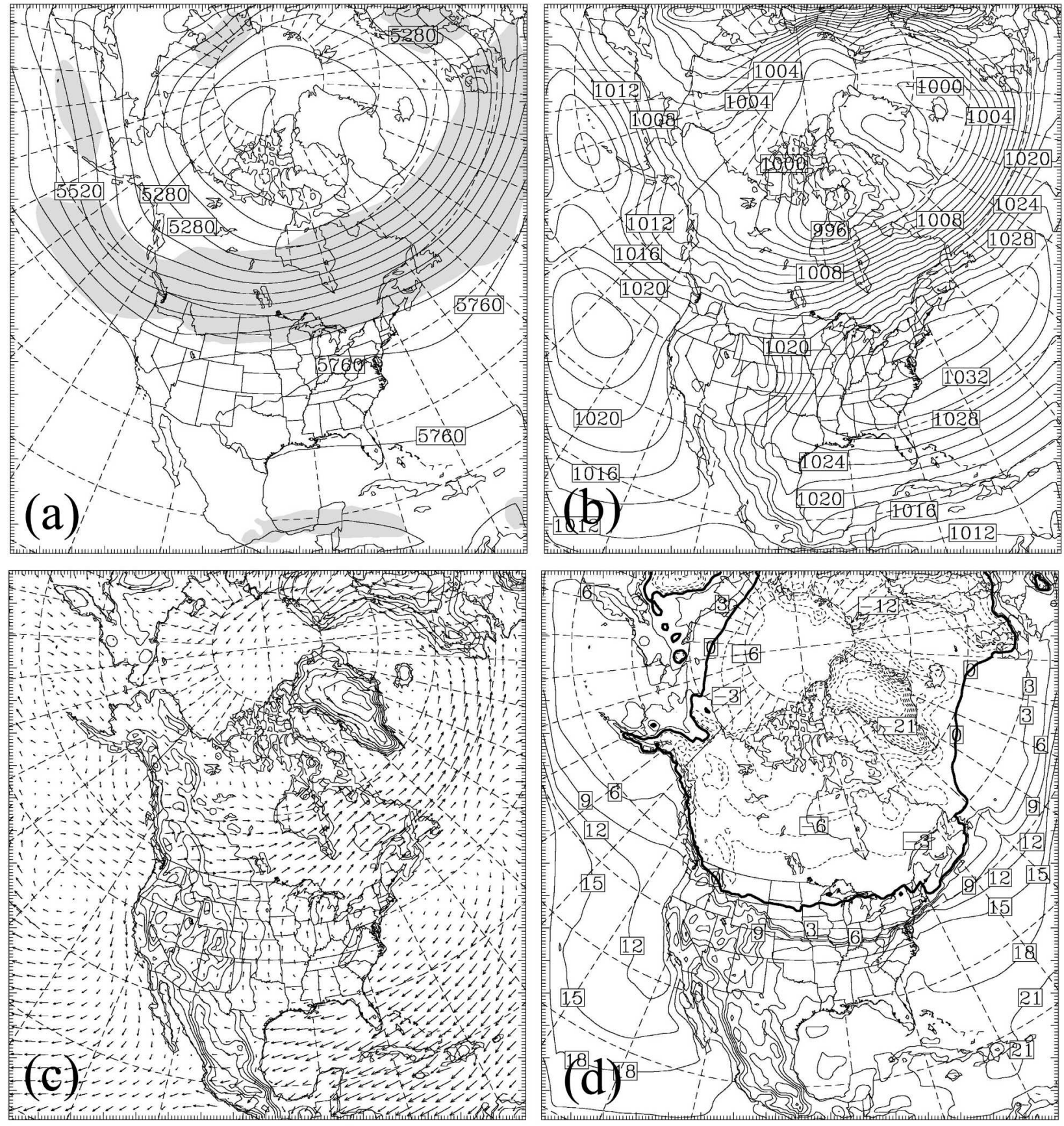

FIG. 10. Polar MM5 mean Jul fields for the flat Laurentide Ice Sheet simulation: (a) 500-hPa geopotential height (contoured every $60 \mathrm{~m}$ ) and wind speeds exceeding $15 \mathrm{~m} \mathrm{~s}^{-1}$ (shaded), (b) sea level pressure (contoured every $2 \mathrm{hPa}$ ), (c) near-surface vector wind and terrain elevation (contoured every $500 \mathrm{~m}$ ), and (d) 2-m air temperature (contoured every $3{ }^{\circ} \mathrm{C} ; 0^{\circ} \mathrm{C}$ isotherm is bold and negative values are dashed).

ciency are included. This simple scheme has been tested in MM5 simulations of an intense midlatitude squall line with robust results (Grell 1993). Chien and Jou (2004) find that the Grell convective scheme, along with the Reisner microphysics parameterization, per- forms well compared to other convective schemes in simulations of summertime mei-yu rain events over Taiwan.

To test the sensitivity of the LGM summer solution to the choice of convective scheme, the July simulation 

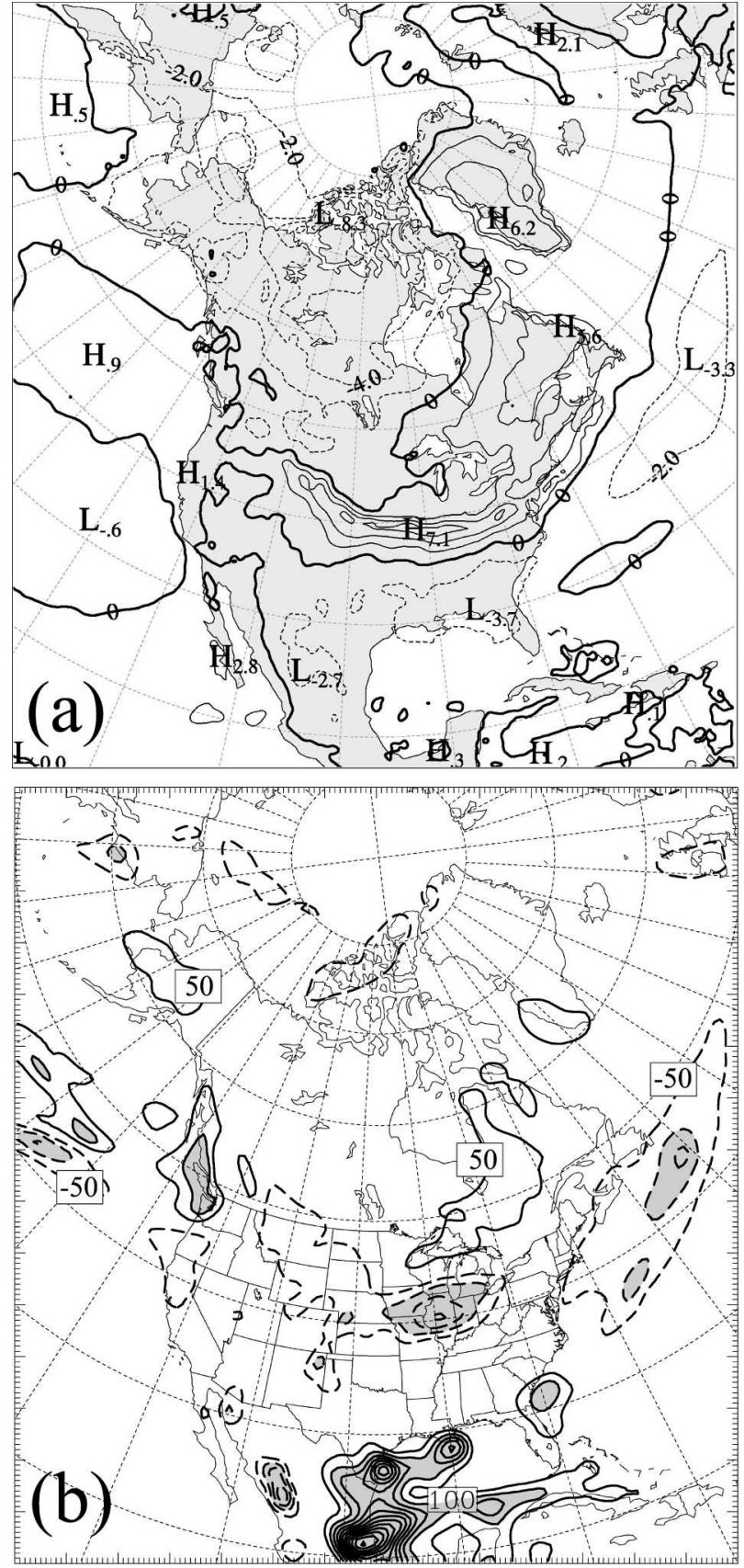

FIG. 11. Polar MM5 mean Jul flat minus full height Laurentide Ice Sheet (a) elevation-corrected 2-m air temperature difference and (b) accumulated precipitation difference. Contour interval is $2^{\circ} \mathrm{C}$ in (a). In (b) the contour interval is $50 \mathrm{~mm}$, anomalies exceeding $\pm 100 \mathrm{~mm}$ are shaded, and the zero contour is not shown. Negative values are dashed in (a) and (b).

was repeated using the modified version of the KainFritsch convective scheme (KF2) (Kain and Fritsch 1993; Kain 2004). The KF2 scheme contains numerous updates to the original Kain-Fritsch convective scheme, including a representation of shallow (non-

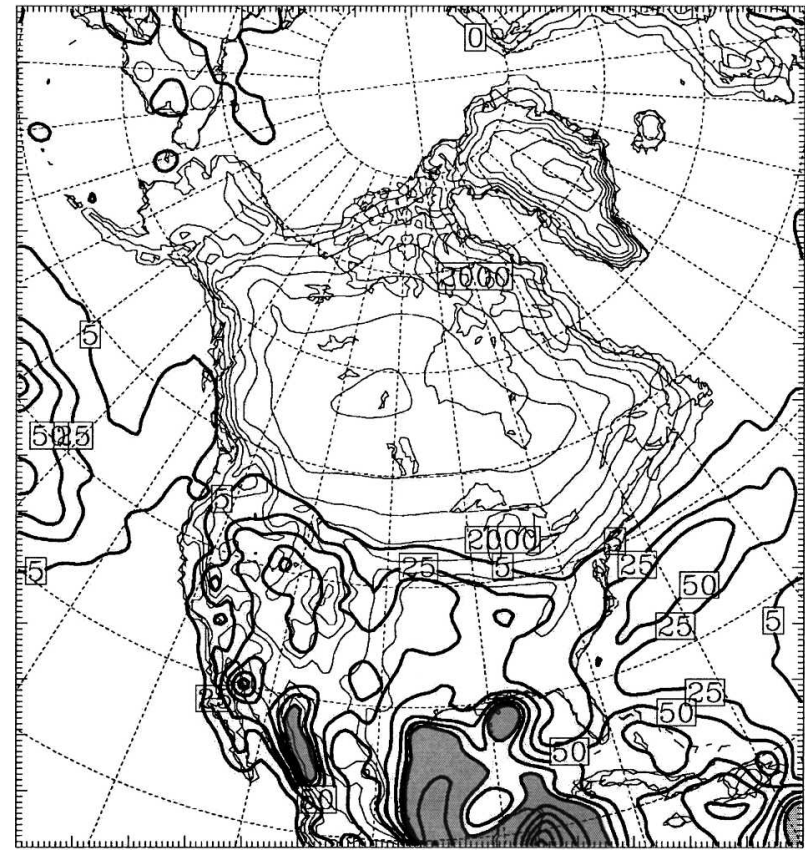

FIG. 12. Polar MM5 LGM JJA accumulated convective precipitation from the Grell cumulus parameterization (thick contours) and terrain elevation (thin contours). Terrain contour interval is $500 \mathrm{~m}$. Precipitation contours are 5, 25, 100, 150, and $200 \mathrm{~mm}$, and every $200 \mathrm{~mm}$ thereafter. Accumulations greater than $200 \mathrm{~mm}$ are shaded.

precipitating) convective clouds, variable cloud depth and cloud radius, a minimum entrainment rate, and the computation of convective available potential energy (CAPE) using an entraining parcel.

Figure 13 shows the July accumulated precipitation (large scale and convective) from the KF2 scheme and precipitation anomalies relative to the control simulation using the Grell scheme. The simulation with KF2 produces a pronounced precipitation maximum near the eastern coast of North America with relatively large accumulations extending across the North Atlantic (Fig. 13a). This belt of enhanced precipitation represents a substantial increase relative to the July control (Fig. 13b). A considerable portion (50-150 mm) of the positive precipitation anomaly along the mid-Atlantic coast is due to increase in convective precipitation from the KF2 scheme (not shown). Along the southern margin of the Laurentide Ice Sheet the KF2 simulation produces reduced precipitation $(40 \%-60 \%)$ compared to the Grell scheme. Here the anomaly is primarily due to a decrease in large-scale precipitation with the KF2 scheme. This shift in the location of the precipitation maximum from the southern margin to the eastern coast also occurs in August and, to a lesser degree, in June (not shown). This suggests that relative to the 

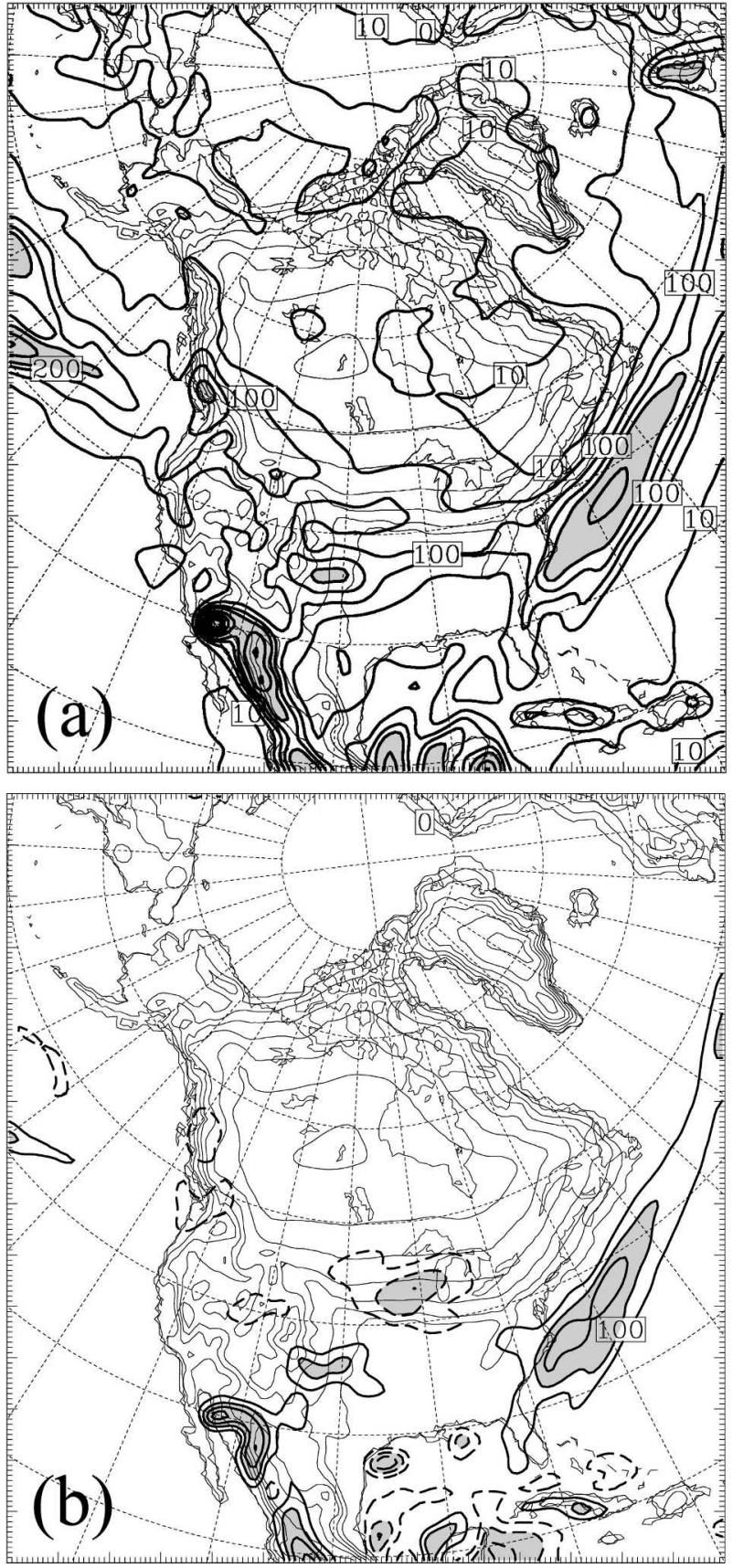

FIG. 13. Polar MM5 LGM July (a) accumulated precipitation (large-scale and subgrid) using the modified Kain-Fritsch (KF2) convective parameterization and (b) precipitation anomalies (KF2 minus Grell). Contours in (a) are 10, 50, 100, 150, and 200 $\mathrm{mm}$, and every $100 \mathrm{~mm}$ thereafter. Accumulations greater than $200 \mathrm{~mm}$ are shaded. Contours in (b) are $\pm 50,100,150$, and 200 $\mathrm{mm}$, and every $100 \mathrm{~mm}$ thereafter. Anomalies exceeding \pm 100 $\mathrm{mm}$ are shaded. Terrain elevation contour interval in (a) and (b) is $500 \mathrm{~m}$.
Grell scheme, the KF2 simulation is producing either a different large-scale atmospheric circulation, a different low-level baroclinic structure along the ice sheet margin, or both.

In terms of the large-scale circulation, the midtropospheric flow from the KF2 run is broadly similar to the July control; the KF2 500-hPa geopotential height field is only slightly amplified $( \pm 60 \mathrm{~m})$ relative to the Grell run (not shown). The KF2 mean July sea level pressure distribution and SLP anomalies relative to the Grell simulation are shown in Figs. 14a and 14b, respectively. The KF2 sea level pressure distribution is qualitatively similar to the Grell control, but with some notable quantitative differences that affect the solution along the southern margin of the Laurentide Ice Sheet. First, the glacial anticyclone, centered west of Hudson Bay, is enhanced in the KF2 run (Fig. 14b), resulting in stronger northerly katabatic winds and lower $\left(1^{\circ}-2^{\circ} \mathrm{C}\right)$ mean July 2-m air temperatures relative to Grell along and south of the ice sheet margin (not shown). The negative SLP anomalies over southeastern North America are due to the fact that the Bermuda high in the KF2 simulation does not extend as far westward as in the Grell run. Thus, there is enhanced southerly near-surface wind flow and slightly higher $\left(2^{\circ} \mathrm{C}\right) 2$-m temperatures over extreme southeastern North America.

The net effect of these circulation changes on the precipitation distribution can be gleaned from examination of the low-level flow. For instance, the low-level $(0.5 \mathrm{~km})$ streamlines over the western Atlantic and southeastern North America from the simulation with the Grell scheme and the KF2 scheme are shown in Figs. 15a and 15b, respectively. The solutions are similar in that both produce broad anticyclonic flow extending from the western North Atlantic westward to the Gulf Coast. With the Grell scheme, the western branch of the anticyclonic circulation (Bermuda high) has a southerly component from the Gulf of Mexico to the southern margin of the Laurentide Ice Sheet where upslope flow occurs and precipitation yield is maximized. With the KF2 scheme, however, the southerly flow on the western branch of the Bermuda high encounters northerly flow from an enhanced anticyclonic circulation centered west of the Great Lakes (Fig. 15b). Lowlevel flow along the southern margin of the ice sheet is downslope, merging with southerly flow around the Bermuda high. The result is a distinct zone of enhanced convergence near the mid-Atlantic coast that coincides with the precipitation maximum (see Fig. 13). Although the causal mechanisms are not clear, the difference in the large-scale circulations produced by the two convective schemes is not entirely unexpected. For instance, Stensrud et al. (2000) find that simulations using 

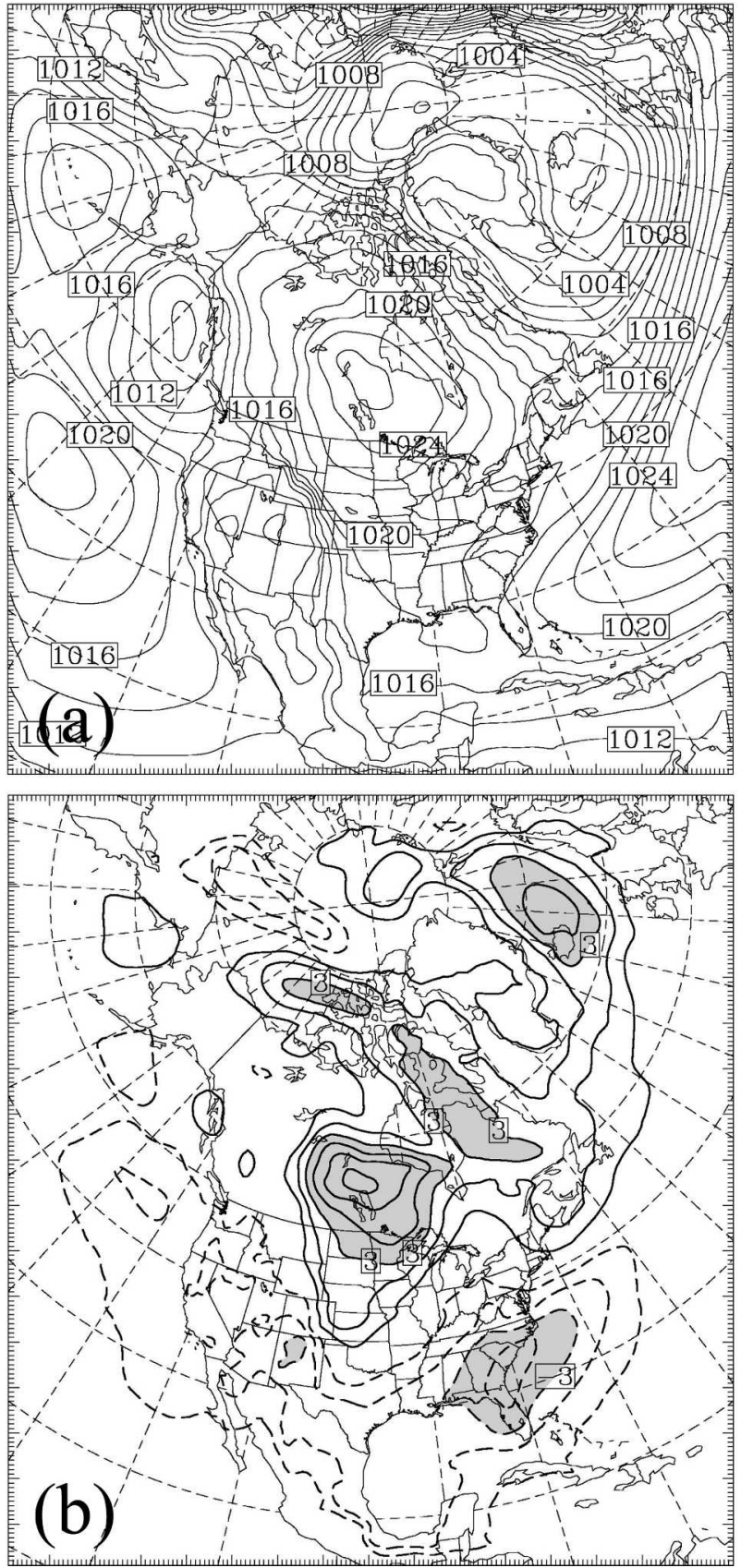

FIG. 14. Polar MM5 LGM mean Jul (a) sea level pressure using the modified KF2 convective parameterization and (b) sea level pressure anomalies (KF2 minus Grell). Contour interval is (a) 2 $\mathrm{hPa}$ and (b) $1 \mathrm{hPa}$. Sea level pressure anomalies exceeding $\pm 3 \mathrm{hPa}$ are shaded.

different convective schemes in the same MM5 model framework with identical initial conditions differ in timing and location of convection. This leads to diverging model solutions over relatively short $(48 \mathrm{~h})$ forecast periods. In the context of the current study, the sensi-
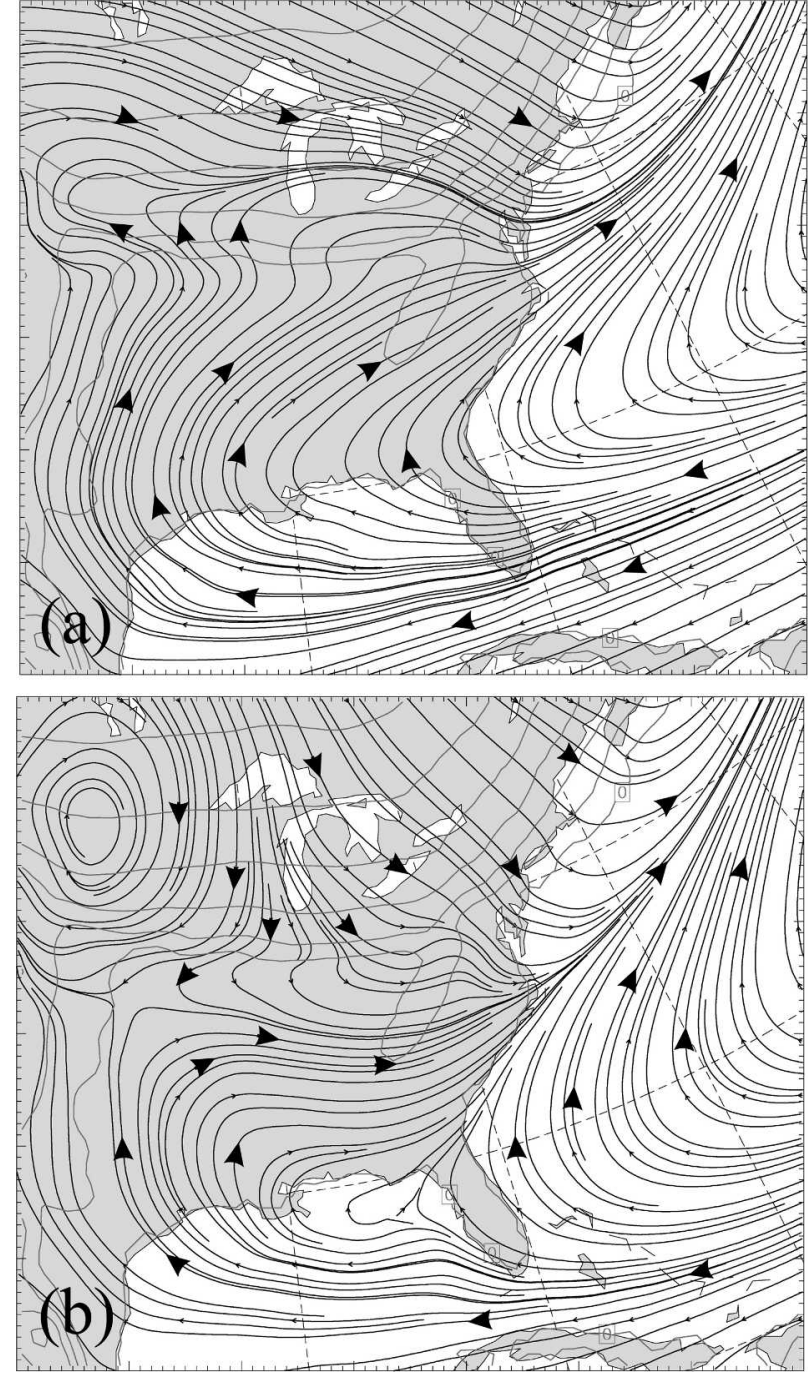

FIG. 15. Polar MM5 LGM terrain elevation (bold contours) and mean Jul low-level $(0.5 \mathrm{~km})$ streamlines using (a) the Grell convective scheme and (b) the modified KF2 convective scheme. Arrows indicate flow direction. Terrain elevation is contoured every $500 \mathrm{~m}$.

tivity experiment demonstrates that relatively minor changes to the large-scale flow are sufficient to strongly influence the distribution of precipitation on the southern margin of the ice sheet.

\section{Discussion}

Bromwich et al. (2004) show that the Laurentide Ice Sheet has a first-order impact on the simulated largescale atmospheric circulation over North America during the LGM winter, primarily through mechanical forcing of the midlatitude westerly flow. Here we find that the Laurentide Ice Sheet also strongly influences 
the large-scale atmosphere during the LGM summer, primarily through baroclinic forcing. In the summer months, near-surface air temperatures along the southern margin of the Laurentide Ice Sheet are close to freezing, while strong insolation (similar to present day) heats the adjacent land surface. The resulting sharp meridional low-level temperature gradient along the ice sheet southern margin anchors the jet stream over the ice sheet and facilitates the development of synoptic cyclones that track over the ice sheet and along the southern margin. This configuration is analogous to the contemporary Arctic frontal zone, a belt of frequent cyclogenesis and frontal activity in the Northern Hemisphere high latitudes. Serreze et al. (2001) find that the Arctic front is most clearly defined in summer and forms in response to differential heating of the snow-free land surface and the adjacent cold Arctic Ocean with some enhancement related to significant orography. Some high-latitude regions receive better than $50 \%$ of their annual precipitation during summer in association with the contemporary Arctic frontal zone. Similarly, our LGM modeling results indicate that over central North America more than half of the annual precipitation occurs during summer (Fig. 16) owing to cyclones and frontal activity across the region.

The summer cyclones simulated by Polar MM5 are capable of producing copious rain on the southern mar-

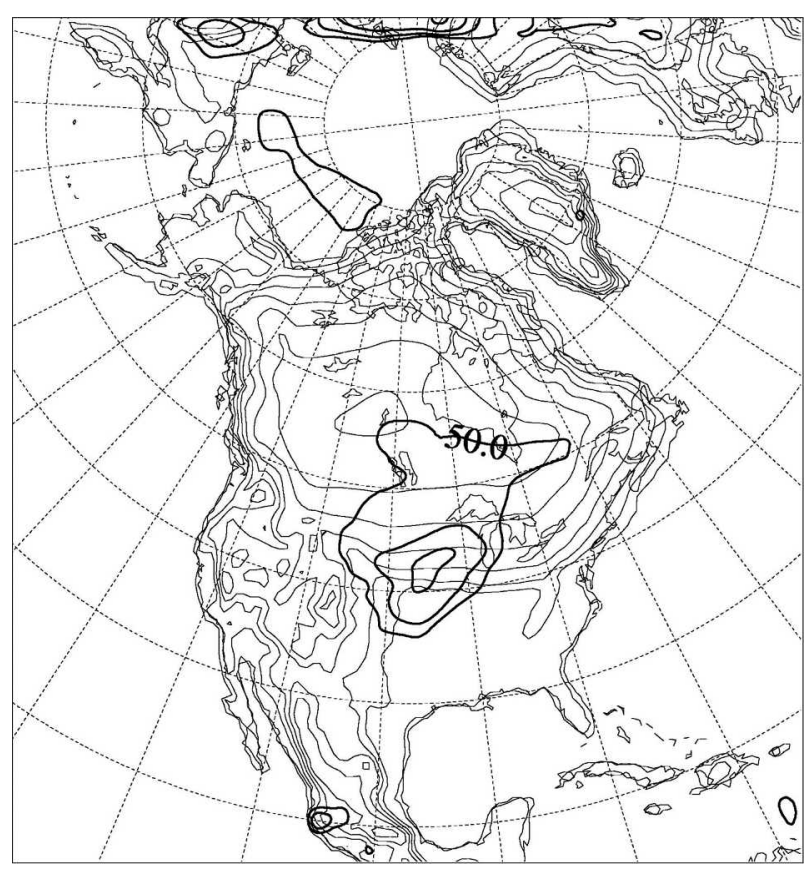

FIG. 16. Polar MM5 LGM fraction of annual precipitation occurring during JJA (bold contours) and terrain elevation (thin contours). Precipitation fraction contour interval is $10 \%$ beginning at $50 \%$. Terrain contour interval is $500 \mathrm{~m}$. gin of the Laurentide Ice Sheet and across the central Great Plains. Notably, the CCM3 LGM simulation, which was used to provide the initial and lateral boundary conditions for Polar MM5, produces upper-level circulation patterns that are broadly similar to the Polar MM5 solution (not shown), but does not capture the heavy rain events along the southern margin. For instance, Table 2 shows the Polar MM5 and CCM3 areaweighted precipitation over the Great Plains (boxed area in Fig. 3) for several model summers. Polar MM5 has greater variability and generally produces $40 \%-$ $70 \%$ more precipitation than CCM3 in this region. We believe that the nature of this discrepancy is similar to that noted by Pan et al. (2004), who found that an RCM coupled to a GCM was better able to capture the summertime low-level circulation (i.e., the low-level jet) and precipitation processes over the central United States, compared to the GCM alone. Bromwich et al. (2004) attribute differences in the LGM winter climate simulated by Polar MM5 and CCM3 to differences in model resolution and physics. Likewise for the summer climate, with higher resolution and optimized physics, Polar MM5 responds more strongly to the presence of the Laurentide Ice Sheet than CCM3 and is better able to simulate the baroclinic processes occurring along the southern margin.

The sensitivity experiment with a flat ice sheet in Polar MM5 clearly demonstrates that orographic lift on the ice sheet southern margin is an important mechanism for generating locally enhanced precipitation. The sensitivity experiment with the modified Kain-Fritsch

TABLE 2. Precipitation statistics over the central United States (boxed area in Fig. 3) for four summer simulations using Polar MM5 and CCM3 (italic).

\begin{tabular}{lcc}
\hline \hline & $\begin{array}{c}\text { Area-weighted } \\
\text { precipitation }(\mathrm{mm})\end{array}$ & $\begin{array}{c}\text { Percent of } \\
\text { summer total }\end{array}$ \\
\hline Jun A & $98(82)$ & $49(43)$ \\
Jul A & $82(59)$ & $41(31)$ \\
Aug A & $20(50)$ & $10(26)$ \\
JJA year A & $200(191)$ & $41(40)$ \\
Jun B & $126(72)$ & $26(23)$ \\
Jul B & $81(41)$ & $33(37)$ \\
Aug B & $104(68)$ & \\
JJA year B & $311(181)$ & $26(26)$ \\
Jun C & $103(36)$ & $43(28)$ \\
Jul C & $122(63)$ & \\
Aug C & $166(37)$ & $50(39)$ \\
JJA year C & $391(136)$ & $20(35)$ \\
Jun D & $119(75)$ & $30(26)$ \\
Jul D & $49(68)$ & \\
Aug D & $71(49)$ & \\
JJA year D & $239(192)$ & \\
\hline
\end{tabular}


convective scheme yields quantitative differences in the distribution of summer precipitation compared to the simulation using the Grell scheme. The Grell scheme generates a precipitation maximum on the southern margin of the ice sheet and the Central Plains. The modified Kain-Fritsch scheme also produces a distinct relative maximum in this region (though roughly $40 \%$ less than Grell), while the absolute maximum is located farther east. Although the precipitation decrease over the Great Plains is considerable, the modified KainFritsch simulation still produces approximately twice the summer precipitation compared to CCM3, suggesting that with either convective scheme the prediction of wet summer conditions on the southern margin of the ice sheet is robust.

Rain on the Laurentide Ice Sheet has important implications for large-scale ice sheet dynamics (Zwally et al. 2002) and for proxy-based interpretations of the LGM climate. For instance, proxy-based estimates of the relative change of precipitation in the Great Plains at the LGM are largely based on loess deposition. Several studies of loess in Colorado, Nebraska, and Iowa suggest a cold and arid climate with inferred sparse vegetation and prevailing westerly or northwesterly winds to efficiently entrain and transport fine-grained sediment from source regions eastward to the central Great Plains (Muhs et al. 1999; Muhs and Bettis 2000; Mason 2001; Muhs and Zárate 2001). In contrast, Polar MM5 produces persistent easterly and northeasterly katabatic winds along and immediately south of the ice sheet terminus in the North American midcontinent and, unlike the CCM3 results and loess-based estimates, is at least seasonally wet.

The summer results from Polar MM5 provide alternate scenarios that may be reconcilable with the proxybased interpretation of general aridity and prevailing westerly winds at the LGM. For instance, because Polar MM5 well captures the katabatic flows over the contemporary continental ice sheets, the katabatic winds simulated along and near the southern margin of the Laurentide Ice Sheet are most likely robust. Hence, it is likely that the surface wind regime in this region would have been dominated by easterly katabatic flow. In the Polar MM5 solution, the persistent easterly katabatic flow in the central Great Plains is confined to within a few model grid points $(<200 \mathrm{~km})$ of the ice sheet terminus from central Nebraska through southern Iowa. South of this katabatic zone, the wind directions are more highly variable and westerly surface winds occur with greater frequency. Thus, if the southern margin of the Laurentide Ice Sheet at the LGM were located slightly farther north than in the current reconstruction, the modeled surface wind directions would be more in agreement with those inferred from loess observations.

The results from Polar MM5 also corroborate the suggestion by Muhs and Bettis (2000) that loess deposition in the central Great Plains may have occurred via strong, low-frequency northwesterly wind events. Polar MM5 simulates a highly amplified precipitation annual cycle in the central Great Plains at the LGM with the majority of the annual precipitation occurring in summer. Unlike the present day, the LGM spring (March through May) is relatively dry with the Central Plains receiving less than $15 \%$ of the annual total precipitation (not shown). However, examination of Polar MM5 output clearly shows synoptic-scale low pressure systems occasionally traversing across the central Great Plains as the jet stream migrates northward across the region. Some of these low pressure systems bring relatively little precipitation to the Central Plains, but are associated with increased low-level wind speed and increased low-level convergence as the storm's cyclonic circulation interacts with the katabatic wind flow along the southern margin of the Laurentide Ice Sheet. Hence, it is plausible that fine-grain loess particles, lofted vertically by episodic, strongly convergent lowlevel wind events, are entrained in the westerly winds above the shallow ( $<100 \mathrm{hPa}$ ) katabatic layer in Polar MM5 and deposited downstream. Muhs and Bettis (2000) cite a contemporary example of a dust storm generated by a strong low pressure system in the Great Plains where dust was observed to heights of $4 \mathrm{~km}$. Our modeling results suggest that these episodic wind events would have most effectively transported loess during a narrow seasonal window as the surface warmed enough to thaw but before the precipitation increase in summer.

Another plausible scenario for loess distribution across the Great Plains involves the role of interannual variability. Additional Polar MM5 LGM summer simulations were run using initial and lateral boundary data from three alternate years of CCM3 output. The LGM boundary conditions and physics options in Polar MM5 were unchanged. Figure 17 shows anomaly fields computed using mean summer data from one of the alternate simulations. Relative to the control summer, the alternate summer simulation produces slightly lower 500-hPa geopotential heights over the Bering Sea region and southwestern and eastern North America and height increases upwind of the Laurentide Ice Sheet and over Greenland and the North Atlantic (Fig. 17a). There are corresponding modest changes in the mean JJA sea level pressure (Fig. 17b). The changes in the level and surface circulation lead to increased northerly near-surface wind flow along and south of the Laurentide Ice Sheet southern margin (not shown) and cooler 

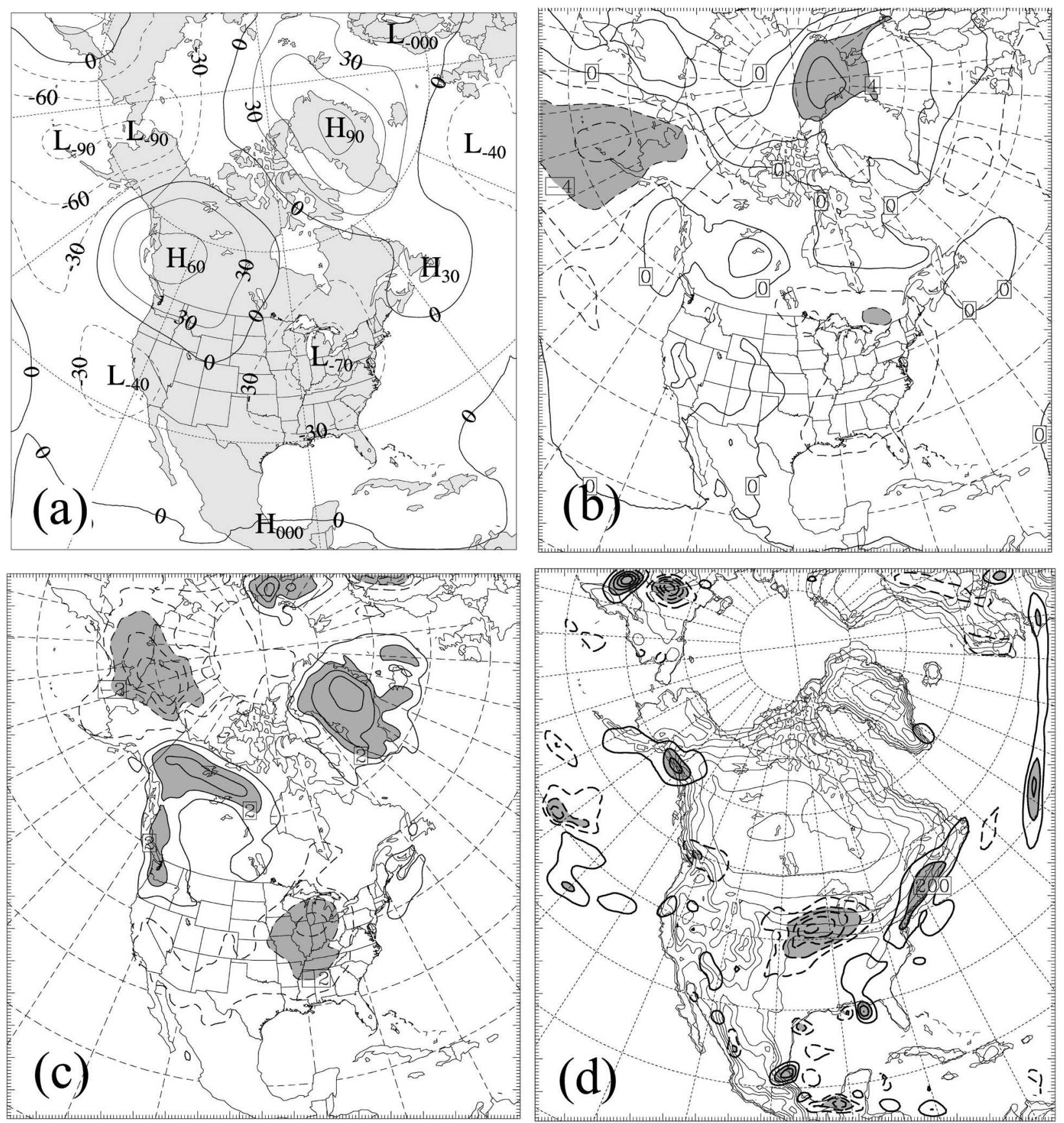

FIG. 17. Polar MM5 LGM alternate mean JJA anomalies (alternate JJA minus control) of (a) 500-hPa geopotential height (contoured every $30 \mathrm{~m}$ ), (b) sea level pressure (contoured every $2 \mathrm{hPa}$ ), (c) 2-m air temperature (contoured every $1^{\circ} \mathrm{C}$ ), and (d) accumulated precipitation (contoured every $100 \mathrm{~mm}$ ) and terrain elevation (contoured every $500 \mathrm{~m}$ ). In (b), anomalies exceeding $\pm 4 \mathrm{hPa}$ are shaded. In (c) anomalies exceeding $2^{\circ} \mathrm{C}$ are shaded. In (d) anomalies exceeding $\pm 200 \mathrm{~mm}$ are shaded, and for clarity the zero contour is not shown. Negative anomalies in each panel are dashed.

2-m air temperatures (Fig. 17c). The negative precipitation anomalies in Fig. 17d represent a substantial $(40 \%-60 \%)$ decrease in accumulated precipitation on the southern margin relative to the control summer (cf. Fig. 3). Results from the other alternate summers are qualitatively similar and demonstrate that modest changes in the atmospheric circulation greatly impact the frequency of cyclones and, hence, the amount of summer precipitation along the Laurentide Ice Sheet southern margin. 


\section{Conclusions}

The LGM summer climate over North America as simulated by Polar MM5 is characterized by a strong low-level thermal gradient along the southern margin of the Laurentide Ice Sheet. This thermal gradient is maintained by the juxtaposition of the cold ice sheet and the adjacent relatively warm land surface, which is heated by insolation similar to that of the present day. As a result, the southern margin of the Laurentide Ice Sheet serves as a zone of enhanced baroclinicity favoring the development of synoptic cyclones that track over the ice sheet and along the margin. Analysis of 3-hourly model output fields indicates that some of these cyclones are capable of producing copious amounts of precipitation along and south of the ice sheet terminus with a high probability that much of this precipitation occurs as rain. A composite of the rain events show that wet periods on the southern margin are characterized by decreased $500-\mathrm{hPa}$ geopotential heights (troughing) over central North America, decreased sea level pressure over the central United States, increased low-level southerly flow from the Gulf of Mexico, and attendant increases in low-level moisture. The low-level southerly flow regime, which resembles a contemporary Great Plains low-level jet configuration, is clearly the primary mechanism of moisture transport to the Central Plains during the LGM. A sensitivity experiment with a flat ice sheet demonstrates the role of ice sheet topography, which orographically enhances precipitation on the southern margin. The composite of dry periods on the southern margin shows anomalous circulation patterns that are distinctly opposite of those associated with the rain events.

The consensus from GCM simulations supports inferences from geological proxy data (e.g., distribution of loess) that the Central Plains south of the Laurentide Ice Sheet was generally arid during the LGM. Furthermore, certain geological landforms in the plains suggest prevailing northwesterly low-level winds during the LGM. While the Polar MM5 depiction of wet summer conditions and prevailing northeasterly (katabatic) winds along the ice sheet terminus appears to be at odds with this interpretation, it corroborates previously proposed alternate climate scenarios that are reconcilable with the observed distribution of loess, namely, sediment entrainment and deposition occurred via strong, but infrequent, northwesterly wind events associated with the passage of low pressure systems through the plains. The Polar MM5 results show that rain events along the southern margin are episodic. While the cyclones traversing the ice sheet are capable of producing strong winds, not all cyclones are able to tap sufficient low-level moisture from the Gulf of Mexico to produce rain along the southern margin. Furthermore, since the modeled easterly katabatic layer is relatively shallow $(<100 \mathrm{hPa})$ with prevailing westerly winds above, strong low-level wind convergence capable of transporting fine-grain sediments through the boundary layer would be a plausible mechanism for downstream loess deposition. Unlike previous GCM simulations, the easterly katabatic zone in Polar MM5 is closely constrained to the ice sheet terminus, suggesting that the low-level wind distribution and loess transport mechanism is sensitive to the precise location (and perhaps the precise configuration) of the ice sheet margin.

In the current study, the specified land surface gives only a general description of the land surface characteristics and does not incorporate the full effects of land-atmosphere interaction. It can be difficult to isolate climate sensitivity to changes in the specified land surface characteristics, such as expanded tundra south of the ice sheet terminus. Several observational and modeling studies in contemporary arctic and subarctic regions demonstrate that the regional and large-scale atmosphere is sensitive to changes in the extent of tundra and boreal forest vegetation (e.g., Bonan et al. 1992; Bonan et al. 1995; Pielke and Vidale 1995). Hence, future work will explore the influence of land surface forcing on the LGM climate using Polar MM5 coupled to a fully interactive land surface model.

Last, Polar MM5 simulations of alternate LGM summers show that relatively minor changes in the largescale circulation have a substantial impact on the distribution of precipitation across the Central Plains. This suggests that variability on interannual (and possibly longer) time scales played a major role in modulating the climate along the southern margin of the ice sheet. Thus, long periods of relatively dry conditions in the Central Plains may have been interspersed with years having wet summers. A sensitivity experiment with the modified Kain-Fritsch convective scheme demonstrates the influence of deep convection on the largerscale circulation, which in turn alters the amount of precipitation south of the ice sheet. While not explicitly examined in this study, the role of tropical sea surface temperature (SST) forcing is inferred since SSTs and their gradients are linked to the distribution of deep convection.

Acknowledgments. This research was funded by National Science Foundation Grants OPP-9905381 and OPP-0352865 to David H. Bromwich. We thank three anonymous reviewers for their constructive suggestions. We greatly appreciate discussions and comments from Mark Anderson and John Kain. Our thanks also 
to Ragharendra Mupparthy for data processing assistance.

\section{REFERENCES}

Bartlein, P. J., and Coauthors, 1998: Paleoclimate simulations for North America over the past 21000 years: Features of the simulated climate and comparisons with paleoenvironmental data. Quat. Sci. Rev., 17, 549-585.

Berger, A., 1977: Long-term variations of the earth's orbital elements. Celestial Mech., 15, 53-74.

Bocchieri, J. R., 1980: The objective use of upper air soundings to specify precipitation type. Mon. Wea. Rev., 108, 596-603.

Bonan, G. B., D. Pollard, and S. L. Thompson, 1992: Effects of boreal forest vegetation on global climate. Nature, 359, 716718.

— , F. S. Chapin III, and S. L. Thompson, 1995: Boreal forest and tundra ecosystems as components on the climate system. Climate Change, 29, 145-167.

Bromwich, D. H., J. J. Cassano, T. Klein, G. Heinemann, K. M. Hines, K. Steffen, and J. E. Box, 2001: Mesoscale modeling of katabatic winds over Greenland with the Polar MM5. Mon. Wea. Rev., 129, 2290-2309.

— A. J. Monaghan, J. J. Powers, J. J. Cassano, H. Wei, Y. Kuo, and A. Pellegrini, 2003: Antarctic Mesoscale Prediction System (AMPS): A case study from the 2000-01 field season. Mon. Wea. Rev., 131, 412-434.

_ , E. R. Toracinta, H. Wei, R. J. Oglesby, J. L. Fastook, and T. J. Hughes, 2004: Polar MM5 simulations of the winter climate of the Laurentide Ice Sheet at the LGM. J. Climate, 17, 3415-3433.

Cassano, J. J., J. E. Box, D. H. Bromwich, L. Li, and K. Steffen, 2001: Evaluation of Polar MM5 simulations of Greenland's atmospheric circulation. J. Geophys. Res., 106, 33, 867-33, 890.

Chien, F.-C., and B. J.-D. Jou, 2004: MM5 ensemble mean precipitation forecasts in the Taiwan area for three early summer convective (mei-yu) seasons. Wea. Forecasting, 19, 735-750.

CLIMAP, 1981: Seasonal Reconstruction of the Earth's Surface at the Last Glacial Maximum. Map and Chart Series, Vol. 36, Geological Society of America, $18 \mathrm{pp}$.

Cook, K. H., and I. M. Held, 1988: Stationary waves of the ice age climate. J. Climate, 1, 807-819.

Cressman, G. P., 1959: An operational objective analysis system. Mon. Wea. Rev., 87, 367-374.

Dong, B., and P. J. Valdes, 2000: Climates at the last glacial maximum: Influence of model horizontal resolution. J. Climate, 13, 1554-1573.

Dudhia, J., 1993: A nonhydrostatic version of the Penn StateNCAR Mesoscale Model: Validation tests and simulation of an Atlantic cyclone and cold front. Mon. Wea. Rev., 121, 1493-1513.

Dyke, A. S., J. T. Andrews, P. U. Clark, J. H. England, G. H. Miller, J. Shaw, and J. J. Veillette, 2002: The Laurentide and Innuitian ice sheets during the Last Glacial Maximum. Quat. Sci. Rev., 21, 9-31.

Edwards, R. L., and Coauthors, 2000: Pollen-based biomes for Beringia 18 000, 6000 and $0{ }^{14} \mathrm{C}$ yr BP. J. Biogeogr., 27, 521554.

Fastook, J. L., and J. Chapman, 1989: A map plane finite-element model: Three modeling experiments. J. Glaciol., 35, 48-52.

- and M. Prentice, 1994: A finite-element model of Antarc- tica: Sensitivity test for meteorological mass balance relationship. J. Glaciol., 40, 167-175.

Felzer, B., R. J. Oglesby, T. I. Webb, and D. E. Hyman, 1996: Sensitivity of a general circulation model to changes in northern hemisphere ice sheets. J. Geophys. Res., 101, 19077 19092.

Giorgi, F., M. R. Marinucci, and G. Visconti, 1990: Use of a limited-area model nested in a general circulation model for regional climate simulation over Europe. J. Geophys. Res., 95, $18413-18431$

Grell, G. A., 1993: Prognostic evaluaton of assumptions used by cumulus parameterizations. Mon. Wea. Rev., 121, 764-787.

-, J. Dudhia, and D. R. Stauffer, 1995: A description of the fifth-generation Penn State-NCAR Mesoscale Model (MM5). NCAR Tech. Note NCAR/TN-398+STR, 122 pp.

Guo, Z., D. H. Bromwich, and J. J. Cassano, 2003: Evaluation of Polar MM5 simulations of Antarctic atmospheric circulation. Mon. Wea. Rev., 131, 384-411.

Hall, N. M., P. J. Valdes, and B. Dong, 1996: The maintenance of the last great ice sheets: A UGAMP GCM study. J. Climate, 9, 1004-1019.

Hostetler, S. W., F. Giorgi, G. T. Bates, and P. J. Bartlein, 1994: Lake-atmosphere feedbacks associated with paleolakes Bonneville and Lahontan. Science, 263, 665-668.

Ji, Y., and A. D. Vernekar, 1997: Simulation of the Asian summer monsoons of 1987 and 1988 with a regional model nested in a global GCM. J. Climate, 10, 1965-1979.

Kageyama, M., and P. J. Valdes, 2000: Impact of the North American ice-sheet orography on the Last Glacial Maximum eddies and snowfall. Geophys. Res. Lett., 27, 1515-1518.

,-- G. Ramstein, C. Hewitt, and U. Wyputta, 1999: Northern Hemisphere storm tracks in present day and Last Glacial Maximum climate simulations: A comparison of the European PMIP models. J. Climate, 12, 742-760.

Kain, J. S., 2004: The Kain-Fritsch convective parameterization: An update. J. Appl. Meteor., 43, 170-181.

_, and J. M. Fritsch, 1993: Convective parameterization for mesoscale models: The Kain-Fritsch scheme. The Representation of Cumulus Convection in Numerical Models, Meteor. Monogr., No. 24, Amer. Meteor. Soc., 165-170.

Kiehl, J. T., J. J. Hack, G. B. Bonan, B. A. Boville, D. L. Williamson, and P. J. Rasch, 1998: The National Center for Atmospheric Research Community Climate Model: CCM3. J. Climate, 11, 1131-1149.

Kutzbach, J. E., and H. E. Wright Jr., 1985: Simulation of the climate of 18, $000 \mathrm{yr}$ BP: Results for the North American/ North Atlantic/European Sector. Quat. Sci. Rev., 4, 147-187.

_, P. J. Guetter, P. J. Behling, and R. Selin, 1993: Simulated climatic changes: Results of the COHMAP climate-model experiments. Global Climates Since the Last Glacial Maximum, H. E. Wright Jr., et al., Eds., University of Minnesota Press, 24-93.

Lamb, H. H., and A. Woodroffe, 1970: Atmospheric circulation during the last ice age. Quat. Res., 1, 29-58.

Manabe, S., and A. J. Broccoli, 1985: The influence of continental ice sheets on the climate of an ice age. J. Geophys. Res., 90, 2167-2190.

Manley, W. F., and D. S. Kaufman, 2002: Alaska PaleoGlacier Atlas: A Geospatial Compilation of Pleistocene Glacier Extents. Vol. 1, Institute of Arctic and Alpine Research (INSTAAR), University of Colorado. [Available online at http://instaar.colorado.edu/QGISL/ak_paleoglacier_atlas.]

Mason, J. A., 2001: Transport direction of Peoria loess in Ne- 
braska and implications for loess sources on the central Great Plains. Quat. Res., 56, 79-86.

Muhs, D. R., and E. A. Bettis III, 2000: Geochemical variations in Peoria Loess of western Iowa indicate paleowinds of midcontinental North America during last glaciation. Quat. Res., 53, 49-61.

- and M. Zárate, 2001: Late Quaternary eolian records of the Americas and their paleoclimatic significance. Interhemispheric Climate Linkages, V. Markgraf, Ed., Academic Press, 183-216.

— J. N. Aleinikoff, T. W. Stafford Jr., R. Kihl, J. Been, S. A. Mahan, and S. Cowherd, 1999: Late Quaternary loess in northeastern Colorado. Part I: Age and paleoclimatic significance. Geol. Soc. Amer. Bull., 111, 1861-1875.

Pan, Z., E. Takle, W. Gutowski, and R. Turner, 1999: Long simulation of regional climate as a sequence of short segments. Mon. Wea. Rev., 127, 308-321.

—, R. W. Arritt, E. S. Takle, W. J. Gutowski Jr., C. J. Anderson, and M. Segal, 2004: Altered hydrologic feedback in a warming climate introduces a "warming hole." Geophys. Res. Lett., 31, L17109, doi:10.1029/2004GL020528.

Peltier, W. R., 2002: On eustatic sea level history: Last Glacial Maximum to Holocene. Quat. Sci. Rev., 21, 377-396.

Pielke, R. A., and P. L. Vidale, 1995: The boreal forest and the polar front. J. Geophys. Res., 100, 25, 755-25, 758.

Powers, J. G., A. J. Monaghan, A. M. Cayette, D. H. Bromwich, Y.-H. Kuo, and K. W. Manning, 2003: Real-time mesoscale modeling over Antarctica: The Antarctic Mesoscale Prediction System (AMPS). Bull. Amer. Meteor. Soc., 84, 15331545.

Qian, J.-H., A. Seth, and S. E. Zebiak, 2003: Reinitialized versus continuous simulations for regional climate downscaling. Mon. Wea. Rev., 131, 2857-2874.

Rind, D., 1987: Components of the ice age circulation. J. Geophys. Res., 92, 4241-4281.

_ 1988: Dependence of warm and cold climate depiction on climate model resolution. J. Climate, 1, 965-997.

Roe, G. H., and R. S. Lindzen, 2001: A one-dimensional model for the interaction between continental-scale ice sheets and atmospheric stationary waves. Climate Dyn., 17, 479-487.

Serreze, M. C., A. H. Lynch, and M. P. Clark, 2001: The Arctic frontal zone as seen in the NCEP-NCAR reanalysis. J. Climate, 14, 1550-1567.

Shinn, R. A., and E. J. Barron, 1989: Climate sensitivity to continental ice sheet size and configuration. J. Climate, 2, 15171537.

Steffen, K., and J. Box, 2001: Surface climatology of the Greenland ice sheet: Greenland Climate Network 1995-1999. J. Geophys. Res., 106, 33, 951-33, 964.

Stensrud, D. J., J.-W. Bao, and T. J. Warner, 2000: Using initial condition and model physics perturbations in short-range ensemble simulations of mesoscale convective systems. Mon. Wea. Rev., 128, 2077-2107.

Svendsen, J. I., and Coauthors, 2004: Late Quaternary ice sheet history of northern Eurasia. Quat. Sci. Rev., 23, 1229-1271.

Tarasov, L., and W. R. Peltier, 2004: A geophysically constrained large ensemble analysis of the deglacial history of the North American ice-sheet complex. Quat. Sci. Rev., 23, 359-388.

Thompson, R. S., and K. H. Anderson, 2000: Biomes of western North America at 18000,6000 , and $0{ }^{14} \mathrm{C}$ yr BP reconstructed from pollen and packrat midden data. J. Biogeogr., 27, 555584 .

Toracinta, E. R., R. J. Oglesby, and D. H. Bromwich, 2004: Atmospheric response to modified CLIMAP ocean boundary conditions during the Last Glacial Maximum. J. Climate, 17, 504-522.

Walters, C. K., and J. A. Winkler, 2001: Airflow configurations of warm season southerly low-level wind maxima in the Great Plains. Part I: Spatial and temporal characteristics and relationship to convection. Wea. Forecasting, 16, 513-530.

Williams, J. W., W. I. Thompson, P. H. Richard, and P. Newby, 2000: Late Quaternary biomes of Canada and the eastern United States. J. Biogeogr., 27, 585-607.

Yang, Z.-L., D. Gochis, and W. J. Shuttleworth, 2001: Evaluation of the simulations of the North American monsoon in the NCAR CCM3. Geophys. Res. Lett., 28, 1211-1214.

Yokoyama, Y., K. Lambeck, P. De Deckker, P. Johnson, and K. Fifield, 2000: Timing of the Last Glacial Maximum from observed sea-level minima. Nature, 406, 713-716.

Zwally, H. J., W. Abdalati, T. Herring, K. Larson, J. Saba, and K. Steffen, 2002: Surface melt-induced acceleration of Greenland ice-sheet flow. Science, 297, 218-222. 